\title{
Millstone coastal quarries of the Mediterranean: A new class of sea level indicator
}

\author{
V. Lo Presti ${ }^{\text {a,* }}$, F. Antonioli ${ }^{\text {b }}$, R. Auriemma ${ }^{c}$, A. Ronchitelli ${ }^{\mathrm{d}}$, G. Scicchitano ${ }^{\mathrm{e}, \mathrm{f}}$, \\ C.R. Spampinato ${ }^{\mathrm{e}, \mathrm{g}}$, M. Anzidei ${ }^{\mathrm{h}}$, S. Agizza ${ }^{\mathrm{i}}$, A. Benini $^{\mathrm{j}}$, L. Ferranti $^{\mathrm{k}}$, \\ M. Gasparo Morticelli ${ }^{\text {a }}$, C. Giarrusso ${ }^{1}$, G. Mastronuzzi ${ }^{\mathrm{m}}$, C. Monaco $^{\mathrm{e}}$, A. Porqueddu $^{\mathrm{n}}$ \\ ${ }^{\text {a }}$ Dipartimento di Scienze della Terra e del Mare, Università degli Studi di Palermo, Italy \\ ${ }^{\mathrm{b}}$ ENEA, UTMEA, Casaccia, Roma, Italy \\ ${ }^{\mathrm{c}}$ Dipartimento di Beni Culturali, Università del Salento, Italy \\ ${ }^{\mathrm{d}}$ U.R. Preistoria e Antropologia - Dip. Scienze Fisiche, della Terra e dell'Ambiente, Università di Siena, Italy \\ ${ }^{\mathrm{e}}$ Dipartimento di Scienze Biologiche, Geologiche ed Ambientali, Università di Catania, Italy \\ ${ }^{\mathrm{f}}$ Studio Geologi Associati T.S.T, Via Galliano 157 Misterbianco, Ct, Italy \\ ${ }^{\mathrm{g}}$ Istituto Nazionale di Geofisica e Vulcanologia, Osservatorio Etneo, sezione di Catania, Ct, Italy \\ ${ }^{\mathrm{h}}$ Istituto Nazionale di Geofisica e Vulcanologia, Roma, Italy \\ ${ }^{\mathrm{i}}$ Via Riviera di Chiaia 215, 80123 Napoli, Italy \\ ${ }^{\mathrm{j}}$ Università della Calabria, Dipartimento di Archeologia e Storia delle Arti, Rende, CS, Italy \\ ${ }^{\mathrm{k}}$ Dipartimento di Scienze della Terra, dell'Ambiente e delle Risorse, Università di Napoli "Federico II", Italy \\ ${ }^{1}$ Via Arborea 17, 07100 Sassari, Italy \\ ${ }^{\mathrm{m}}$ Dipartimento di Scienze della Terra e Geoambientale, Università degli Studi “Aldo Moro", Bari, Italy \\ ${ }^{\mathrm{n}}$ Via. E. Arborea, 07024, La Maddalena, Olbia-Tempio, Italy
}

\section{A R T I C L E I N F O}

\section{Article history:}

Available online 5 April 2014

\section{Keywords:}

Coastal quarry

Oil millstone

Relative sea level changes

Archaeological sea level marker

\begin{abstract}
A B S T R A C T
The coasts of Italy still preserve several remnants of coastal quarries built in antiquity, that now provide insights into the intervening sea-level changes occurred during the last millennia. In this paper, we show and discuss a new class of sea level indicator consisting of millstones carved along the rocky coast of southern Italy since $2500 \mathrm{BP}$, that are currently submerged. They were extracted from beachrocks, sandstones or similar sedimentary rocks, easier for carving by ancient carving tools. Our study focuses on 10 coastal sites located at Capo d'Orlando, Avola, and Letojanni, in Sicily; Soverato, Tropea, and Capo dell'Armi, in Calabria; Castellabate, Palinuro, and Scario, in Campania; and Polignano San Vito, in Apulia.

Unfortunately, only limited archaeological information is available for these anthropic structures. Scario, one of these millstone quarries discussed here, has been dated through independent archaeological remains, allowing us to restrict the exploitation age to the end of XVII century. Present day elevations of these coastal sites were obtained through geo-archaeological surveys calibrated using the nearest tidal stations, together with geomorphological and tectonic interpretations. Data were compared against the latest sea level predictions based on glacio-hydro-isostatic models. Our results allow proposal of the age-range of these millstone quarries and to estimate the intervening relative sea level changes since the time when they were carved.
\end{abstract}

(c) 2014 Elsevier Ltd and INQUA. All rights reserved.

\section{Introduction}

Many archaeological sites located along the Italian coast are today totally or partially submerged due to the eustatic sea level rise and Global Isostatic Adjustment (GIA) or negative vertical

\footnotetext{
* Corresponding author.

E-mail address: valeria.lopresti@gmail.com (V. Lo Presti).
}

tectonic movements. Data from these sites have been used as paleo sea level markers for the late Holocene (Flemming, 1969; Schmiedt, 1972; Lambeck et al., 2004; Antonioli et al., 2007; Scicchitano et al., 2008; Auriemma and Solinas, 2009; Anzidei et al., 2011a,b).

Coastal archaeological sites, used as powerful indicators of past sea levels are prehistoric and proto-historic settlements such as port installations (concrete slabs, docks, piers, slide hauling, docks, dry docks, etc.), residential units (Villae maritimae) and their 
annexes such as fish ponds, public or private buildings (foundations, floors, walkways, roadways, etc.), plumbing (wells, aqueducts, cisterns, sewers, culverts, drainage channels), tombs, and beached shipwrecks. These sites, described in Auriemma and Solinas (2009), were strictly related to past sea levels and tidally controlled. Lambeck et al. (2004) proposed for the first time a minimum "functional elevation" for coastal quarries at about $60 \mathrm{~cm}$ above sea level, enough to load the quarried stones on boats. In contrast to coastal quarries, archaeological information for the age and use of millstone quarries still does not exist, preventing their use in the definition of past sea level.

Scicchitano et al. (2011) analyzed the millstone coastal quarries located at Capo dell'Armi (Calabria) and Capo d'Orlando (Sicily) (Fig. 1). Geomorphological surveys conducted along the Italian coasts during the last years allowed the discovery of many ancient millstone quarries, some of which, such as at Giardini Naxos in Sicily and Roccella Ionica in Calabria (Fig. 1), are buried by beach deposits.

The aims of this work are to: 1) give an archaeological overview about type and areal distribution of millstone; 2) study their different carving techniques; 4) provide their age; and 5) give a knowledge contribution for these important archaeological remains, presently at high risk of erosion due to the high erodibility of the rocks on which they were carved, and the continuing sea level rise and coastal erosion, that may cause their total disappearance in the future.

\subsection{Millstone quarries}

Millstone (Fig. 2a) is documented in southern Italy since around 2500 BP (Amouretti, 1986; Amouretti and Brun, 1993; Brun, 1997). Their sizes and shapes fit the carving systems used at those times, characterized by cylindrical or slightly truncated cone shape wheels that turn perpendicularly above a subjacent horizontal wheel of similar size placed above a masonry base (Amouretti, 1986; Hadjisavvas, 1992; Brun, 1997; Rosada, 2007).

Their use is reported since the beginning of the Hellenistic period, but a large spread in the Mediterranean basin is evident from the Roman to the modern age. After the XIX century, this traditional crusher system was progressively abandoned (Amouretti and Brun, 1993). According to literary archaeological sources, coastal quarrying was one of the best logistic solution for the difficulties of heavy stone transport (Orlandos, 1968; Dworakowska, 1975; Rockwell, 1992; Kozelj and Wurch Kozelj, 1993; Felici Buscemi and Felici, 2004). For this reason, the millstones were carved and transported on boats or barges almost exclusively through waterways (rivers and sea) (Orlandos, 1968; Dworakowska, 1975; Rockwell, 1992; Felici Buscemi and Felici, 2004; Belmont, 2011; Jaccottey, 2011; Felici and Lanteri, 2012), land transport being too complex and expensive (Bessac, 1986).

The use of waterways for millstone transportation is attested by underwater findings because they were often falling from ships, even in places far from the coasts from which they were carved.

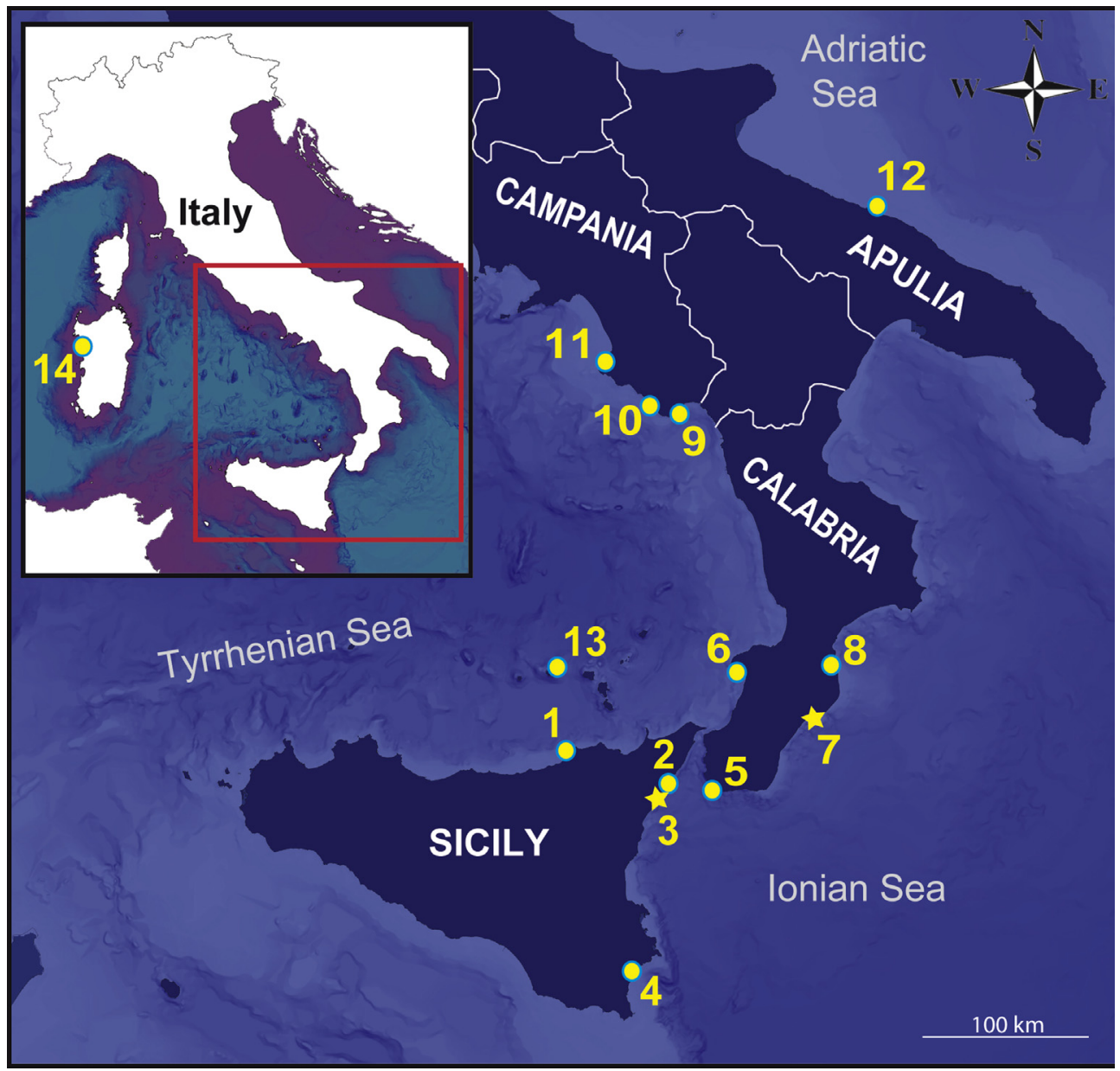

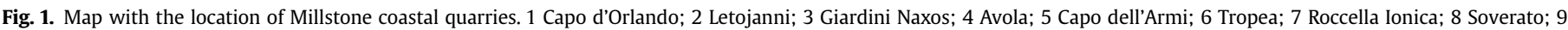
Scario; 10 Palinuro; 11 Castellabate; 12 Polignano San Vito; 13 Filicudi; 14 Bosa. 


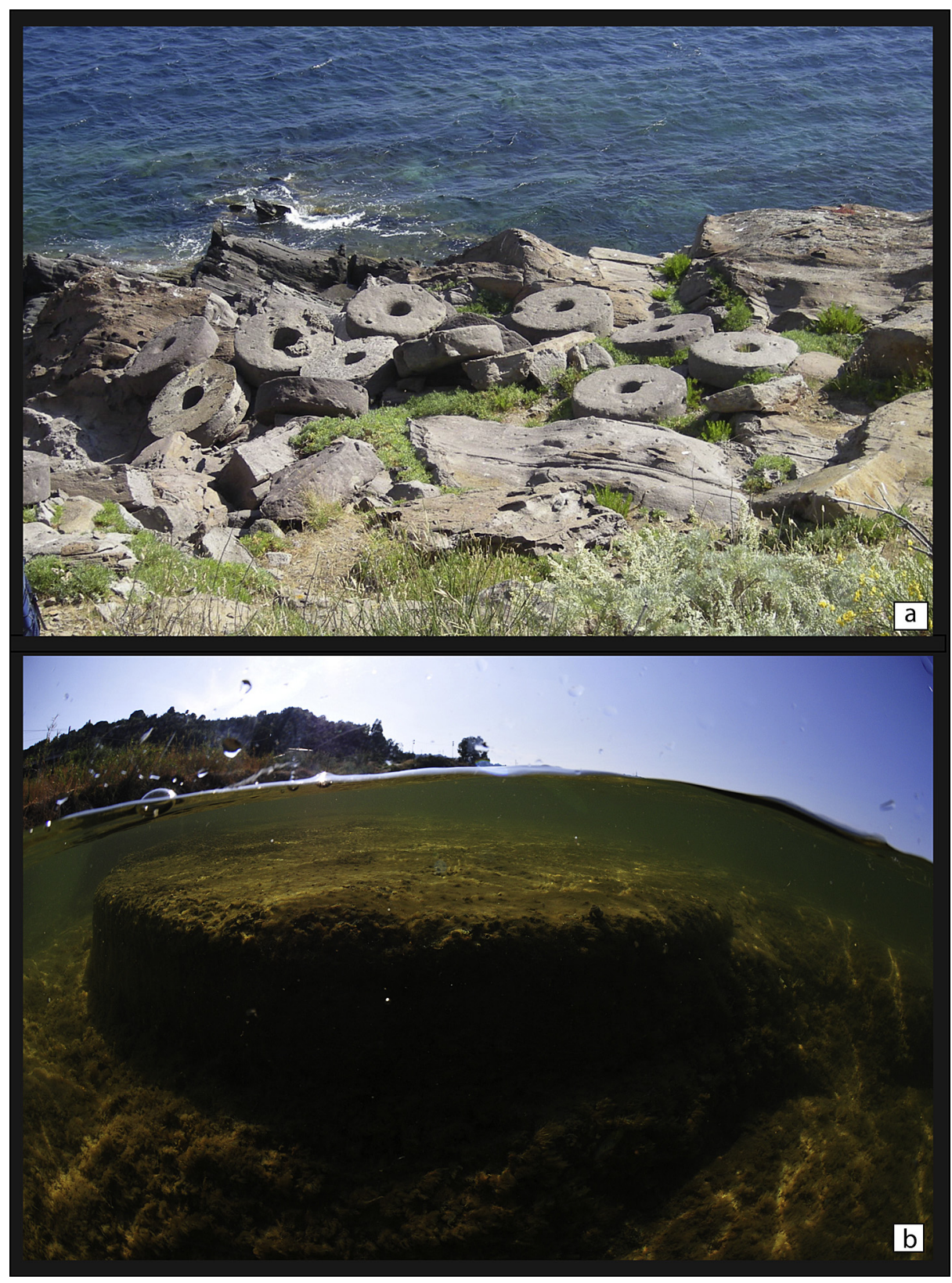

Fig. 2. Abandoned Millstone at Filicudi quarry (a); Capo d'Orlando quarry partially or totally submerged (b).

Their age is mainly from Greek-Roman times (of smaller size and turned manually, “Pompeian" type, Peacock, 1986, 1989), but also to medieval and post-medieval times.

Most of these quarries are at present submerged (Fig. 2b), but at the time of their use were carved above sea level, in order to facilitate the extractive activity. No archaeological information exists to understand the functional height of their separation/ extraction plans and the type of boats used, likely barges. Moreover, little is known about the modalities of boarding, that probably occurred using derricks.

In addition to southern Italy, coastal quarries of cylindrical grinders (more than $1 \mathrm{~m}$ in diameter) are also found along the French coast. These are usually dated to the middle or postmedieval ages and are associated with water or wind mills and human or animal traction (Belmont and Mangartz, 2006; Belmont, 2006a,b; Williams and Peacock, 2011). The Cap d'Ail millstone quarry (Provence, France), which is about one hundred meters long and ten hundred meters wide, shows about one hundred extraction sockets and some hewn wheels. The extraction was practiced on the sedimentary layers. Grinding wheels are still in place and millstone fragments occur below sea level. Here, several millstones used for water mills (therefore for wheat milling) or olive oil, with diameters ranging from 49 to $103-142 \mathrm{~cm}$, have been extracted. These were linked with the pre-Roman or Roman settlement of Mont Bastide in Eze, occupied from the II century BC to the II century A.D., in some areas until the Late Antiquity (Amouretti and Brun, 2002; Geist, 2003).

However, the largest millstone found in this site can be dated from the Middle Ages to the modern age. The morphological characteristics of the Cap d'Ail millstone quarry are similar to examples of the southern Iberian coast (Anderson and Scarrow, 2011) and to those studied in this work. 


\subsection{Millstone utilization}

Archaeology, history, literary, iconographic and archival sources suggest that millstones were designed both for grain grinding and olive pressing during various periods (Fig. 2a, b). Minor uses were for the milling of all kinds of seed oils (i.e. castor, sesame, in Egypt; walnut oil in France; Amouretti and Brun, 1993) but also for breaking lime and gypsum stones. Grinding millstones used for cereal milling, dated to Greek or late- Republican age, had, generally, small size and diameter between 25 and $40 \mathrm{~cm}$ (for crushers with manual rotary mechanism) or between 45 and $80 \mathrm{~cm}$ (Williams-Thorpe, 1988, 1993). Larger stones were used for water mills (Vitruvius, X; Plinius, XVII; Wikander, 1979, 1984), as the millstones discovered in Atene (Parsons, 1936), Roma (Bell, 1994: Wilson, 2001; Humphrey et al., 2006) France: Barbegal, Martresde-Veyre, Mesclans with mole in basalt, Les Laurons (II-III A.D.), in Marseille and La Calade (V century A.D.) (Benoit, 1940; Amouretti, 2002). In addition, stones of larger size were also dated to the medieval/modern period as in Palermo province (Sicily, Italy), in the first half of the XVII century, but there are older examples dating to the XII century (archival data).

The Middle and Modern age millstones are similar to those we studied, i.e., morphometric studies of the French quarry of Claix (Les Meulieres, XIX century). Millstones with diameter of $0.80-$
$1.40 \mathrm{~m}$ are referred to Middle age; millstones with diameters of 1.50-1.75 m to between XVII and XIX centuries (Belmont, 2011).

\subsection{Olive oil millstone distribution and size}

Millstones were used in mills for grinding olives since the late Archaic period (VI-V century BC; Amouretti, 1986; Amouretti and Brun, 1993; Brun, 1997, 2004), introducing an important technical and economic innovation. Archaeological records are limited, because of poor knowledge about rural Mediterranean archeology (Columella XII; Amouretti and Brun, 2002; Brun, 2004). Dating millstones is difficult because they are often found in coastal areas without historical and archaeological references.

The oldest evidence is found at Pindakas, Chios (V century BC) (Boardman, 1958-1959; Amouretti and Brun, 1993; Foxhall, 1993), Olinto in Greece (IV century BC) (Brun, 2004), Argilos and Vrasna in Macedonia (IV-III century BC); different sites in Attica (Lohmann, 1993), Maresha in Palestine (III cent. BC.) (Kloner and Sagiv, 1993), Adrano in Sicily (Brun, 2004) and Corinth (before 146 BC), related to the oldest type of mill: the "trapetum" (Fig. 3a).

Millstones are mentioned by Columella (Columella, XII; Amouretti and Brun, 1993; Frankel, 1993; Humphrey et al., 2006) and are found in Italy in many Villae rusticate such as at Settefinestre, (I century BC.; Carandini, 1985), Seccareccio, Tolfa Mounts
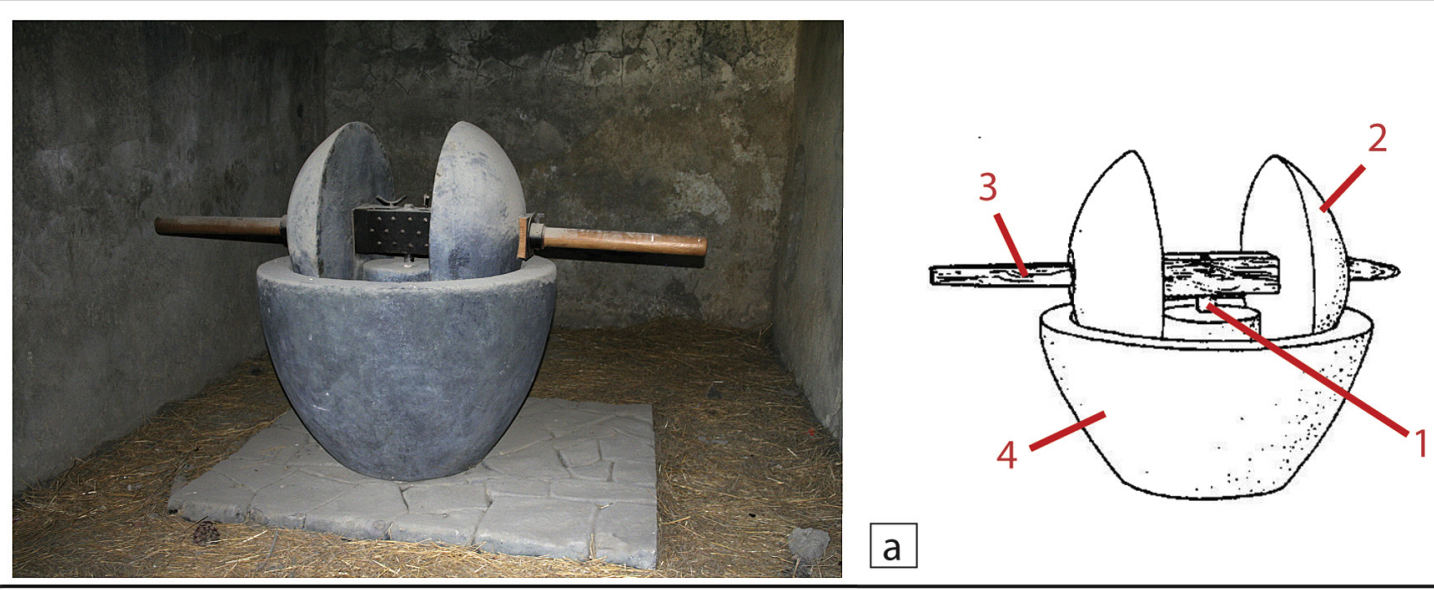

a
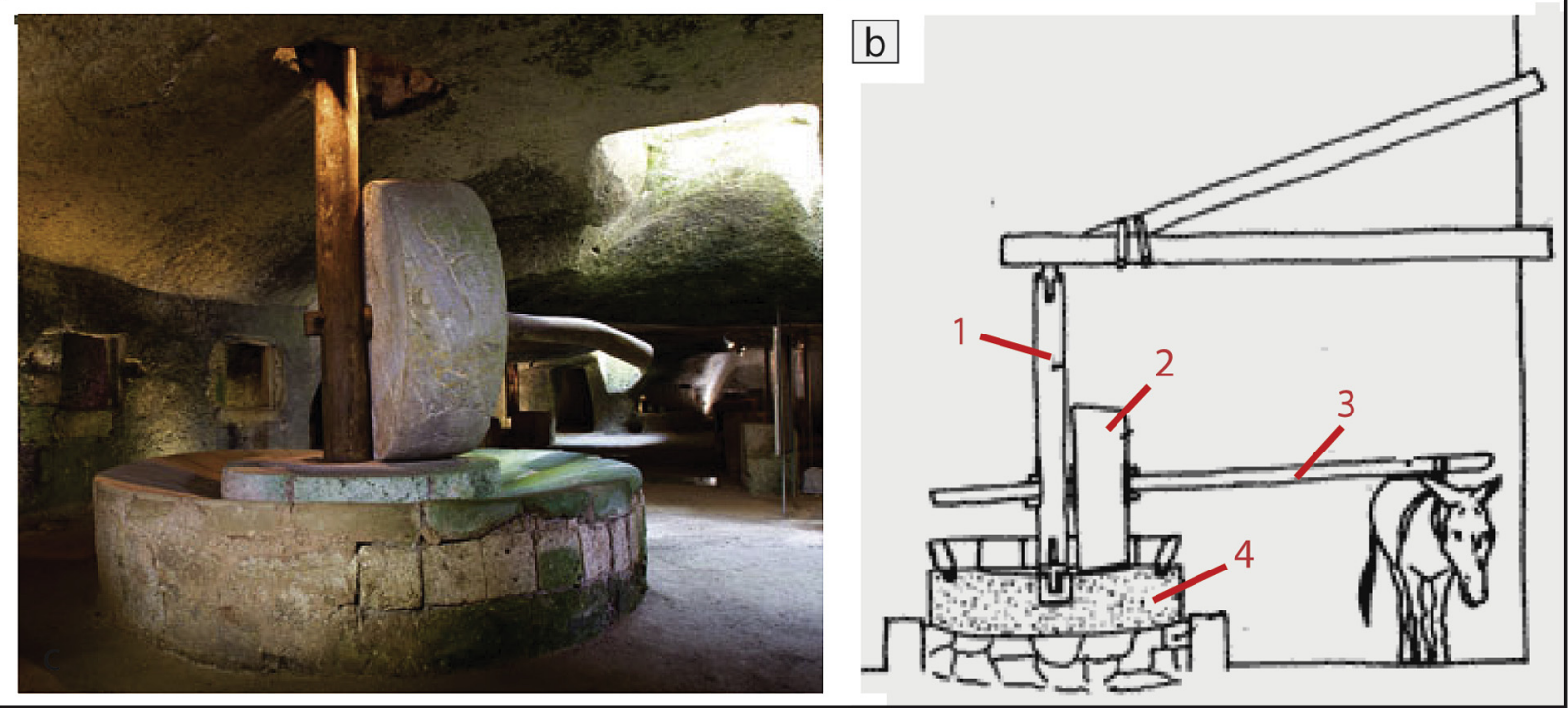

Fig. 3. Mill typology. The "Trapetum” (a); olives pressing mill (b). 1 Columella; 2 Millstone; 3 Cupa; 4 Mortarium. 
(Maffei and Nastasi, 1990), Radogna (northern Apulia; Volpe, 1996) and along the northern-central Adriatic coasts (Busana et al., 2009; Tassaux, 2010). Millstones are found also in France, at Glanum, Pousaraque, Peymenade and eastern Linguadoca. Only those at Candéou Peymenade are dated to the mid-second century A.D. (Amouretti and Brun, 1993; Gateau, 1997).

African sites have millstones with large diameters of 1.1-1.6 m (Mattingly and Hitchner, 1993; Brun, 2004), such as the Trapetum, found at Dougga in Tunisia (Amouretti and Brun, 1993). In Istria and Dalmatia, millstones are found in rural and urban sites (Matijašić, 1993, 2007; Glicksman, 2007; Starac, 2010) (Fig. 3).

Mills for grinding olives (Fig. 3) have unchanged features from the Hellenistic to the modern age (Stradan, XVI century; Amouretti et al., 1984). These were utilized until a few decades ago in Sicily (Bianca, XIX century) and in Portugal until the XX century.

Hellenistic and Roman millstones were built with very different diameters, from about $70 \mathrm{~cm}$ in Gallia (Amouretti and Brun, 1993; Gateau, 1997); 84-96 cm at Cyprus (Hadjisavvas, 1992); 100$110 \mathrm{~cm}$ in Umag, Croazia (Matijašić, 2007); to $115 \mathrm{~cm}$ at Settefinestre, Italy. The "sottomola" diameter (Fig. 3 ) is very different, but always larger than that of a millstone: $140-150 \mathrm{~cm}$ at Marea, Egipt; Mari-Kopetra, Cipro; Cosa; Antella (Carandini, 1985; Hadjisavvas, 1992); $162 \mathrm{~cm}$ at Desenzano (Scagliarini Corlàita, 1994); and $237 \mathrm{~cm}$ at Tivoli (Faccenna, 1957).

The millstones carved in Sicily during the XIX century show a diameter of $130 \mathrm{~cm}$. From the Middle Ages to the XVII century the size became larger, with diameter greater than $150 \mathrm{~cm}$ and thickness up to $40-50 \mathrm{~cm}$. These were used in mills with part of rotating mechanisms moved by large animals (Amouretti, 1986).

Considering the great economic value that millstones have during the past human history, they were often reused after the decommissioning of mills. All types of millstone were probably carved according to similar mechanisms and the rounded profile was acquired by subsequent machining processes.

\subsection{The mills}

Cato, De Agri Coltura, describes the oldest type of mill: the "Trapetum" (Fig. 3a). Millstones studied in this work were utilized in another type of mill described by Columella XII; Carandini (1985); Acquaviva (1995) (Fig. 3b): a cylindrical/frustoconical millstone that rotates perpendicularly to a standing millstone: the "sottomola" (or mortarium) of the same size, with a vertical pole (columella) which rotates on itself. On this pole, a horizontal axis ("cupa") is fixed to the vertical millstone; animal or manual pushing rotates the vertical millstone, grinding olives thrown in the tank (Fig. 3). An Italian origin was attributed to this type of mill (Amouretti and Brun, 1993) but it was present since the Hellenistic period in Israel (Yeivin, 1966) and Cyprus (Hadjisavvas, 1992), and in the whole Mediterranean basin from Roman to modern age, until the XIX century, after which mills for grinding olives were no longer used.

\section{Methods}

In this work, we have studied 10 sites. We rely on recently published tectonic work in order to establish if some of these sites have been affected by vertical tectonic movements.

Long term coastal vertical displacement rates have been obtained (Table 2) from the present elevation of markers of the Last Interglacial highstand (MIS 5.5) and late Holocene highstands. MIS 5.5 and late Holocene fossil deposits and forms are well developed along the coasts of Mediterranean and offer an excellent opportunity to discern broad patterns of differential displacement within adjacent tectonic sectors (Ferranti et al., 2010; Lambeck et al., 2011).

Measurements of the current elevations of archaeological and geomorphological markers with respect to the current sea level at the time of the surveys were performed by an invar rod (decimetric rod composed by alternating red and white sections). During the last decade, a densely distributed tidal network, that includes more than 30 stations, has been established in the Italian region. To achieve a precise measurement of the elevation of the investigated sites discussed in this paper, we used real time tidal data from the ISPRA network (http://www.mareografico.it/). We have analyzed 11 years of tidal recording at the individual stations located near the investigated archaeological sites to determine a local mean sea level. We then used the estimated local mean sea level values to correct the elevation of the millstone quarries with respect to sea level measurements obtained during field surveys. In this way we obtained the reference zero level at the individual tidal stations closest to the studied sites. The elevation of the lowest carvings of the millstone quarries were subsequently computed with respect to the obtained mean sea level value valid for the investigated area. In our analysis, we neglected the effect of the glacio-hydro-isostatic signals acting during this time span, which is included in the tidal data, as its contribution is within a few $\mathrm{mm}$ of amplitude. Measurements and corrections are reported in Table 1.

Table 1

Millstone elevation and tidal correction.

\begin{tabular}{|c|c|c|c|c|c|c|c|c|}
\hline Site no. & Location & $\begin{array}{l}\text { Reference tide } \\
\text { gauge station }\end{array}$ & $\begin{array}{l}\text { Measurement date } \\
\text { and time (GMT) }\end{array}$ & $\begin{array}{l}\text { Mean sea level at } \\
\text { reference tidal stations } \\
2001-2011(\mathrm{~cm})\end{array}$ & Tide value $(\mathrm{cm})$ & Tide correction $(\mathrm{cm})$ & $\begin{array}{l}\text { Millstone } \\
\text { quarries } \\
\text { elevation }(\mathrm{cm})\end{array}$ & $\begin{array}{l}\text { Corrected elevation } \\
\text { s.l.m. }(\mathrm{cm})\end{array}$ \\
\hline 1 & $\begin{array}{l}\text { Capo } \\
\text { d'Orlando }\end{array}$ & Palermo & $\begin{array}{l}15.09 .2009 \\
09.00 \\
04.06 .2011 \\
10.00\end{array}$ & $\begin{array}{l}-9.4 \\
-9.4\end{array}$ & $\begin{array}{l}+15 \\
+19\end{array}$ & $\begin{array}{l}\text { High: }+5.6 \\
\text { High: }+9.6\end{array}$ & $\begin{array}{l}-40 \\
-0.38\end{array}$ & $\begin{array}{l}-34.4 \\
-28.4\end{array}$ \\
\hline 2 & Letojanni & Catania & $\begin{array}{l}20.12 .2012 \\
12.30\end{array}$ & 3.2 & +4 & High: +1 & -38 & -37 \\
\hline 4 & Avola & Catania & $\begin{array}{l}03.07 .2013 \\
11.20\end{array}$ & 3.2 & +6 & High: +3 & -40 & -37 \\
\hline 5 & $\begin{array}{l}\text { Capo } \\
\text { dell'Armi }\end{array}$ & Reggio Calabria & $\begin{array}{l}15.09 .2009 \\
13.00\end{array}$ & 18.7 & -4 & High: +14.7 & -40 & -25.3 \\
\hline 6 & Tropea & $\begin{array}{l}\text { Reggio Calabria } \\
\text { Palinuro }\end{array}$ & $\begin{array}{l}27.05 .2011 \\
11.00\end{array}$ & $\begin{array}{l}18.7 \\
12.2\end{array}$ & $\begin{array}{l}-10.0 \\
-21.0\end{array}$ & $\begin{array}{l}\text { High: }+8.7 \\
\text { Low: }-8.8 \\
\text { Medium: }-0.1\end{array}$ & -40 & -40.1 \\
\hline 8 & Soverato & Crotone & 03.06.2010 & 17.2 & -10 & High: +7.2 & -30 & -22.8 \\
\hline
\end{tabular}


Table 1 (continued)

\begin{tabular}{|c|c|c|c|c|c|c|c|c|}
\hline Site no. & Location & $\begin{array}{l}\text { Reference tide } \\
\text { gauge station }\end{array}$ & $\begin{array}{l}\text { Measurement date } \\
\text { and time (GMT) }\end{array}$ & $\begin{array}{l}\text { Mean sea level at } \\
\text { reference tidal stations } \\
2001-2011(\mathrm{~cm})\end{array}$ & Tide value $(\mathrm{cm})$ & Tide correction $(\mathrm{cm})$ & $\begin{array}{l}\text { Millstone } \\
\text { quarries } \\
\text { elevation }(\mathrm{cm})\end{array}$ & $\begin{array}{l}\text { Corrected elevation } \\
\text { s.l.m. }(\mathrm{cm})\end{array}$ \\
\hline 9 & Scario & Palinuro & $\begin{array}{l}28.05 .2011 \\
12.30\end{array}$ & 12.2 & -7 & High: +5.2 & -20 & -14.8 \\
\hline 10 & Palinuro & Palinuro & $\begin{array}{l}28.05 .2011 \\
18.00\end{array}$ & 12.2 & +2 & High: +14.2 & -54 & -40 \\
\hline 11 & Castellabate & Salerno e Palinuro & $\begin{array}{l}19.04 .2013 \\
12.00\end{array}$ & $\begin{array}{l}-15.16 \\
-12.24\end{array}$ & $\begin{array}{l}-22 \\
-16\end{array}$ & $\begin{array}{l}\text { Low: }-7 \\
\text { Low: }-4\end{array}$ & -80 & -85.5 \\
\hline 12 & $\begin{array}{l}\text { Polignano } \\
\text { San Vito }\end{array}$ & Bari & $\begin{array}{l}14.06 .2010 \\
07: 40 \\
02.11 .2013 \\
13.40\end{array}$ & $\begin{array}{l}15.0 \\
15\end{array}$ & $\begin{array}{l}-19 \\
0\end{array}$ & $\begin{array}{l}\text { Low: }-4 \\
\text { High: }+15\end{array}$ & $\begin{array}{l}-20 \\
-30\end{array}$ & $\begin{array}{l}-24 \\
-15\end{array}$ \\
\hline
\end{tabular}

For each site we assumed that quarry floor corresponds to the lowest level of the millstone quarry with respect to the local sea level, i.e. the deepest carved level of the rock outcrop (Fig. 4). Diameter and thickness of extraction imprints were also measured (Fig. 4, Table 2). excavation of circular rings next to each other to maximize outcrop exploitation. The inner parts of these rings correspond to millstones that were extracted. Ring diameters, millstone diameters, and thickness changes in the individual quarry sites are between $115-185 \mathrm{~cm}, 90-150 \mathrm{~cm}$ and $20-35 \mathrm{~cm}$, respec-

Table 2

Location, tectonics, millstone lithology, morphometry and height above sea level.

\begin{tabular}{|c|c|c|c|c|c|c|c|c|c|}
\hline Site no. & Location & $\begin{array}{l}\text { Coordinates } \\
\text { (Lat, Lon) }\end{array}$ & Lithology & $\begin{array}{l}\text { Rings } \\
\text { diameter }(\mathrm{cm})\end{array}$ & $\begin{array}{l}\text { Millstone } \\
\text { diameter }(\mathrm{cm})\end{array}$ & $\begin{array}{l}\text { Millstone } \\
\text { thickness }(\mathrm{cm})\end{array}$ & $\begin{array}{l}\text { Deposit } \\
\text { altitude (m): } \\
\text { MIS } 5.5 \\
\text { Late Holocene }\end{array}$ & $\begin{array}{l}\text { Uplift rate } \\
\text { mm|yr: } \\
\text { MIS 5.5 } \\
\text { Late Holocene }\end{array}$ & $\begin{array}{l}\text { Quarry } \\
\text { altitude } \\
\text { b.s.l. }(\mathrm{cm})\end{array}$ \\
\hline 1 & Capo d'Orlando & $\begin{array}{l}38.1540^{\circ} \mathrm{N} \\
14.7725^{\circ} \mathrm{E}\end{array}$ & Sandstone (Oligocene-Miocene) & $160-185$ & $130-150$ & 20 & $\underline{60}$ & +0.38 & -31.4 \\
\hline 2 & Letojanni & $\begin{array}{l}37.8874^{\circ} \mathrm{N} \\
15.3172^{\circ} \mathrm{E}\end{array}$ & Conglomerate (Oligocene) & $160-170$ & 141 & 38 & $\frac{114}{5}$ & $\frac{+0.9}{+1.4}$ & -37 \\
\hline 4 & Avola & $\begin{array}{l}36.9034^{\circ} \mathrm{N} \\
15.1481^{\circ} \mathrm{E}\end{array}$ & $\begin{array}{l}\text { Sandstone } \\
\text { Pliestocene }\end{array}$ & $115-170$ & $80-150$ & $30-35$ & 6 & $\underline{0}$ & -37 \\
\hline 5 & Capo dell'Armi & $\begin{array}{l}37.9511^{\circ} \mathrm{N} \\
15.6909^{\circ} \mathrm{E}\end{array}$ & Beachrock (Late Holocene) & $130-155$ & $110-130$ & 25 & $\frac{130}{1}$ & $\frac{+1}{+1}$ & -25.3 \\
\hline 6 & Tropea & $\begin{array}{l}38.6711^{\circ} \mathrm{N} \\
15.8693^{\circ} \mathrm{E}\end{array}$ & Sandstone (Miocene) & 115 & 90 & 23 & $\frac{120}{2.2}$ & $\frac{+0.67}{+1.4}$ & -40.1 \\
\hline 8 & Soverato & $\begin{array}{l}38.5964^{\circ} \mathrm{N} \\
16.5535^{\circ} \mathrm{E}\end{array}$ & Beachrock (Late Holocene) & 150 & $110-122$ & $20-25$ & 92 & $\underline{+0.78}$ & -22.8 \\
\hline 9 & $\begin{array}{l}\text { Scario (quarry } \\
\text { located at sea level) }\end{array}$ & $\begin{array}{l}40.0403^{\circ} \mathrm{N} \\
15.4787^{\circ} \mathrm{E}\end{array}$ & $\begin{array}{l}\text { Conglomerate (Last Interglacial } \\
\text { with Strombus } b \text { ) }\end{array}$ & $165-180$ & $130-160$ & 35 & 10 & $\underline{0}$ & -14.8 \\
\hline 10 & Palinuro & $\begin{array}{l}40.0444^{\circ} \mathrm{N} \\
15.2839^{\circ} \mathrm{E}\end{array}$ & Conglomerate (Last Interglacial) & 160 & 105 & $20-30$ & $\underline{3}$ & $\underline{0}$ & -40 \\
\hline 11 & Castellabate & $\begin{array}{l}40.4382^{\circ} \mathrm{N} \\
14.9775^{\circ} \mathrm{E}\end{array}$ & Sandstone (Pleistocene) & $140-180$ & $120-160$ & $30-35$ & $\underline{9}$ & $\underline{0}$ & -85.5 \\
\hline 12 & Polignano San Vito & $\begin{array}{l}41.01510^{\circ} \mathrm{N} \\
17.19312^{\circ} \mathrm{E}\end{array}$ & $\begin{array}{l}\text { Sandstone (upper Pliocene- } \\
\text { middle Pleistocene) }\end{array}$ & $120-130$ & 100 & 20 & $\underline{3}$ & $\underline{0}$ & -19.5 \\
\hline
\end{tabular}

\section{Data analysis}

\subsection{Geomorphological and geotechnical setting}

Field surveys highlight the morphometric features of millstones and quarry floors (Figs. 4-6; Table 2):

1) Morphology of rocky outcrops on which the millstone were carved: rocky outcrops are slightly sloping towards the sea. They have widths between 10 and $40 \mathrm{~m}$ and lengths (parallel to the coast) that range from tens to hundreds of meters. Seawards, the quarry floor commonly ends with a cliff. Due to the high economic value of millstones, they have been extracted from coastal outcrops having the required characteristics. We also found isolated rocks, a few meters distant from the coast, with only one or two extraction rings (Fig. 6b)

2) Excavation technique: millstones were extracted, where possible, following the sedimentary layers. According to our observations (in the absence of archaeological literature about carving methodology), the quarrying process probably started with the tively (Table 2). In Polignano San Vito, Palinuro, and Scario, where the thickness of bedrock was sufficient, two/three millstones were carved, one upon the other, using the previous excavation rings.

3) Different seaward limit of quarry plans:

- on one case, the outcrop ends with a steep slope or a submerged morphological step (2-4 $\mathrm{m}$ high), that allowed both landing and loading of millstones on small boats, and limited the sea ingression during high tide (Fig. 7a);

- on another case, the outcrop is slightly sloping towards the sea. The millstone is presently partially buried by beach sediments (Fig. 7b).

The only clear difference between the analyzed quarries is the floor depth with respect to the sea levels that varies between $-14.8 \mathrm{~cm}$ (Scario quarry) and $-85.5 \mathrm{~cm}$ (Castellabate quarry) (Fig. 8, Table 2). In Table 2, the geographical location of the sites, the lithology of quarried rocks, the altitude of MIS 5.5 and/or late-Holocene deposits, the uplift rates values of unstable sites and the correct height of quarry floors are reported. 


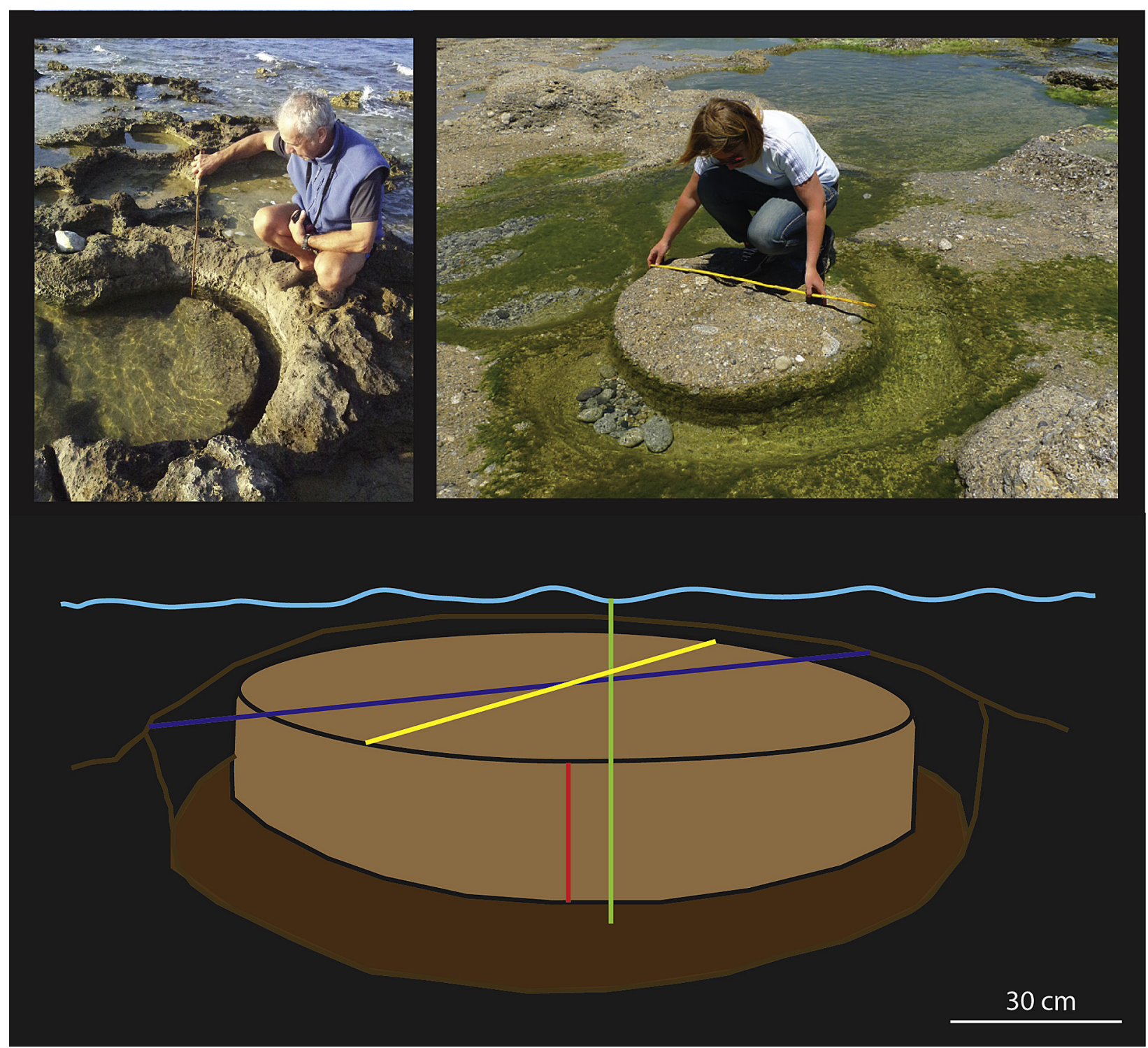

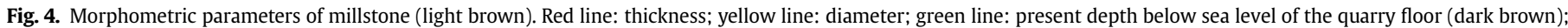
blue line: ring diameter. (For interpretation of the references to colour in this figure legend, the reader is referred to the web version of this article.)

Repeated measurements of the quarry floor were done at Capo d'Orlando and Polignano San Vito sites during different epochs. The difference between repeated measurements is only a few $\mathrm{cm}$, which falls in the error margin of the used survey techniques. As in this study we have collected measurements at centimetric level (Tables 1 and 2), tidal correction is crucial to obtain reliable results.

Popular memories and literature data (Spigo, 2004b) note that at Giardini Naxos in Sicily and Roccella Ionica in Calabria (Fig. 1) there are millstone quarries completely covered by beach deposits, exposed during occasional heavy storms. Therefore, we think that other millstone coastal sites should exist in southern Italy, buried by beach deposits, while others are exposed to marine and subaerial erosion (Furlani et al., 2009).

\subsection{Coastal quarries: geological and archaeological features}

The geological analysis of investigated sites show quarry floors with common lithological characteristics: these are rocky outcrops particularly erodible and easy to carve, such as calcarenites, conglomerates, sandstone, and beach rock (Table 2) which, in stable areas, are of Last Interglacial age.

\subsubsection{Sicily}

Capo d'Orlando (Figs. 1 and 5a) (described by Scicchitano et al., 2011) is carved within the Stilo-Capo d'Orlando Formation (Upper Oligocene-Lower Miocene, Bonardi et al., 1980; Carbone et al., 1998): gray-yellowish sandstone and polygenic conglomerates, unconformably overlaying Paleozoic metamorphic rocks. Sandstones are often covered by sandy and gravelly alluvial deposits. According to literary sources, Agathyrnus, the legendary city founded by the homonym child of Eolo, was located there. The area shows evidence of settlement since the beginning of II millennium BC, that is the recent Bronze age (Scibona, 1985; Pinzone, 2004; Spigo, 2004a,b). Due to its strategic geographical position, the area was also populated in Archaic and Hellenistic ages (Bonanno, 2004). The Roman phase is well documented: in the Bagnoli area, near the studied millstone quarry, known as the Mercadante quarry (Fig. 5a), a landing and a villa with thermal complex dated between 


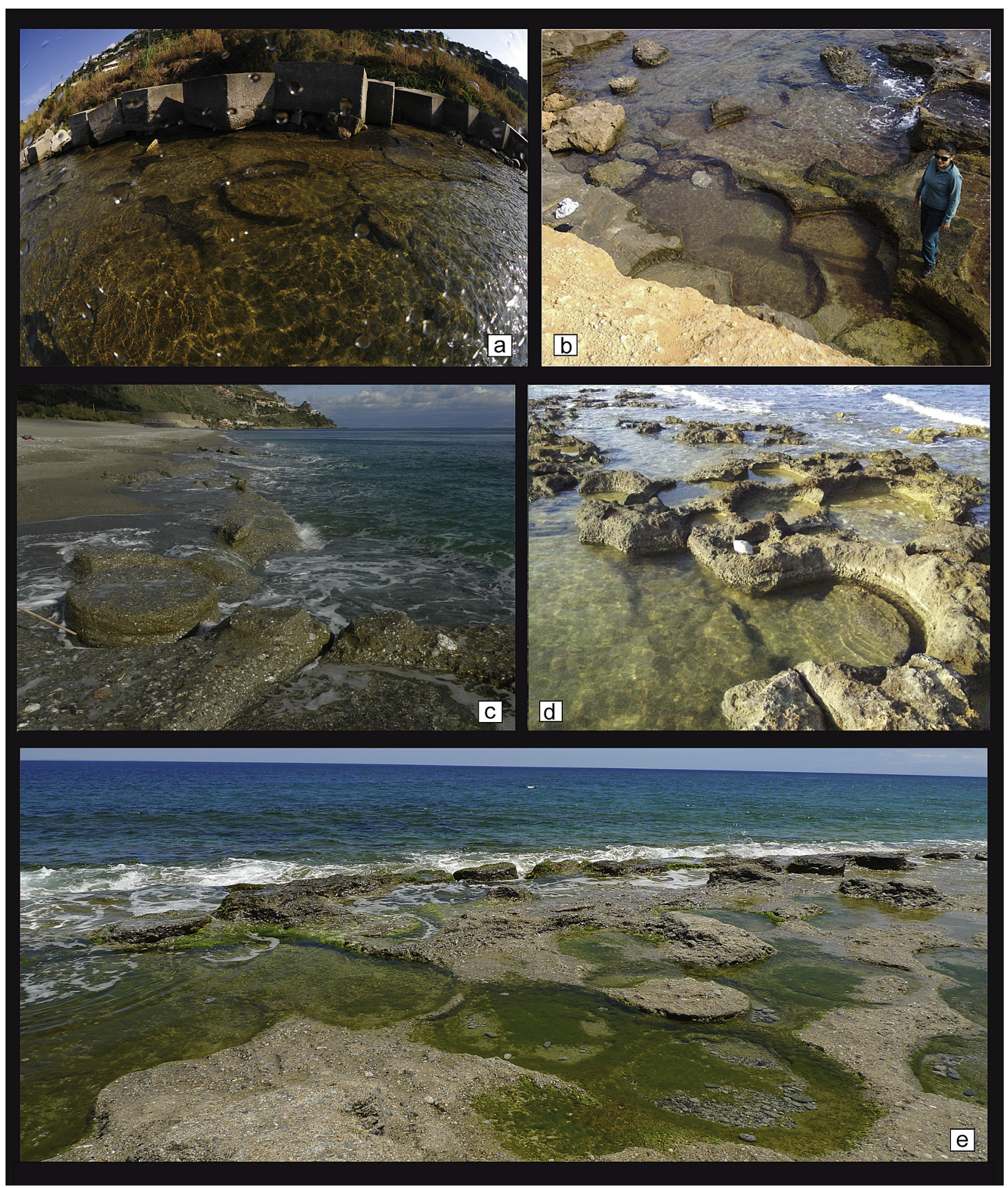

Fig. 5. Panoramic view of millstone coastal quarries: Capo d'Orlando (a); Avola (b); Letojanni (c); Polignano San Vito (d); Soverato (e).

III and V sec. BC have been found. The complex shows evident signs of destruction, probably due to one or more earthquakes (Spigo, 1995; Ollà, 2004; Spigo et al., 2004; Spigo, 2004a,b). This is a tectonically unstable area, and a Holocene vertical uplift rate of $0.38 \mathrm{~mm} /$ year has been estimated (Sulli et al., 2013, Table 2). The quarried coastal stretch is $150 \mathrm{~m}$ long, and more than 100 carved millstones have been counted.

Avola quarry (Figs. 1 and 5b) is carved in Quaternary biocalcarenites (Di Grande and Raimondo, 1982). On the basis of last
Interglacial and Holocene sea level markers (Antonioli et al., 2009; Ferranti et al., 2010), we consider this area stable. The quarried coastal stretch is $30 \mathrm{~m}$ long with less than 50 millstones carved.

Letojanni quarry (Figs. 1 and $5 c$ ) is carved in lower Oligocene polygenic conglomerates characterized by well-rounded crystalline clasts. The rocky outcrop has maximum thickness of about $2 \mathrm{~m}$ and is often covered by beach deposits. It gently slopes seaward down to $-3 \mathrm{~m}$ (Ucosich, 2011). The MIS 5.5 and late Holocene markers measured at Taormina, $2 \mathrm{~km}$ to the south, at altitude of 114 and $5 \mathrm{~m}$, 

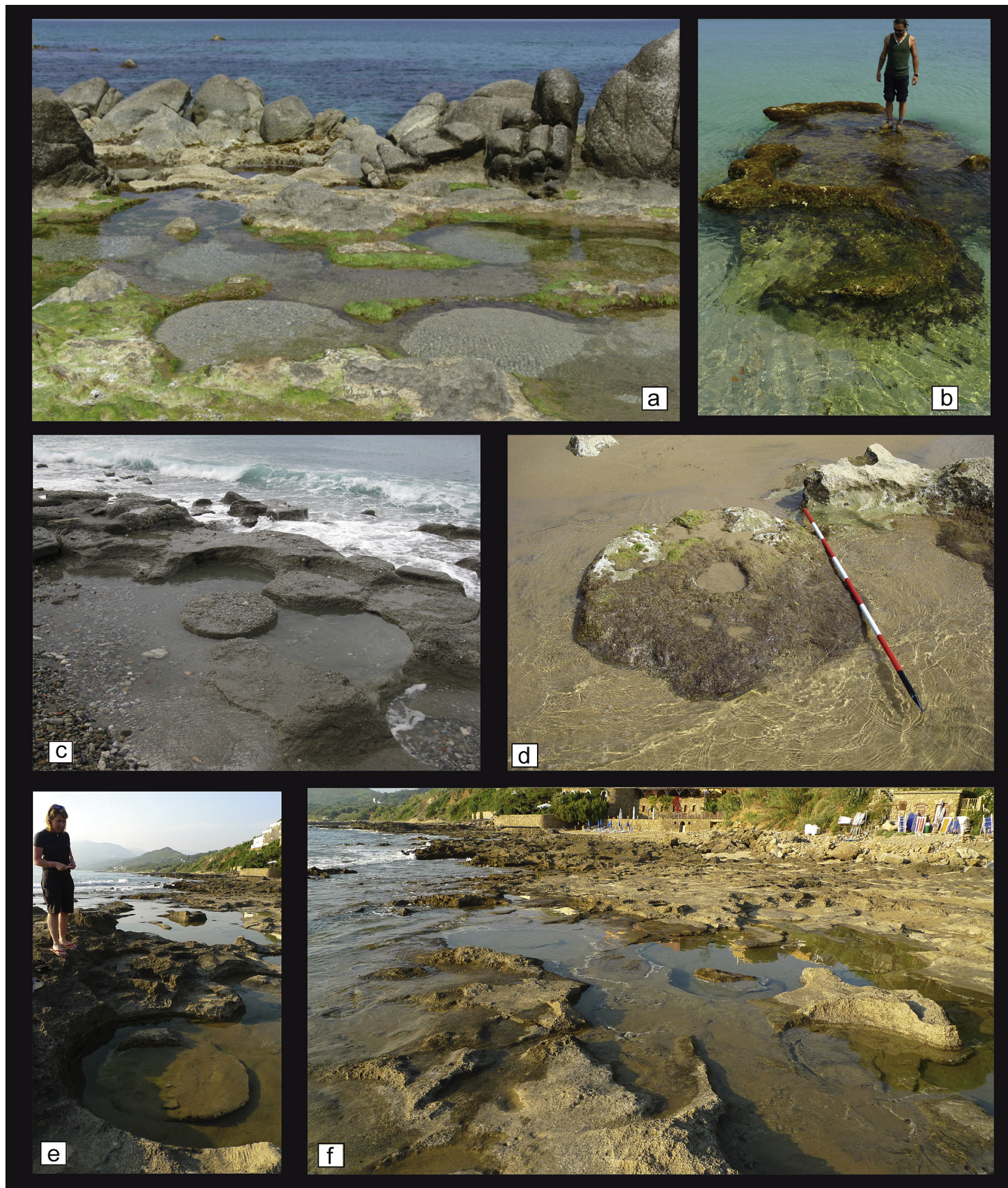

Fig. 6. Panoramic view of millstone coastal quarries: Tropea (a,b); Capo dell'Armi (c); Castellabate (d); Palinuro (e, f).

respectively, suggest recent vertical deformation with uplift rates ranging from 0.9 to $1.4 \mathrm{~mm} /$ year (Ferranti et al., 2010; Spampinato et al., 2012). The quarried coastal stretch is $30 \mathrm{~m}$ long, with less than 50 millstones carved.

\subsubsection{Apulia}

At Polignano San Vito (Figs. 1 and 5d), discontinuous PlioPleistocene marine deposits, attributed to the Calcarenite di
Gravina Formation, occur (Ciaranfi et al., 1988). They are constituted of bioclastic coarse sandstones, very rich in fossil remains and ichnotraces (Iannone and Pieri, 1979; D'Alessandro and Iannone, 1984), frequently fractured as consequence of Late Quaternary tectonics. Geomorphological evidence suggests that this area has been considered stable since the Late Pleistocene (Mastronuzzi and Sansò, 2002; Lambeck et al., 2004; Ferranti et al., 2006). On the Calcarenite di Gravina, an extensive surf 

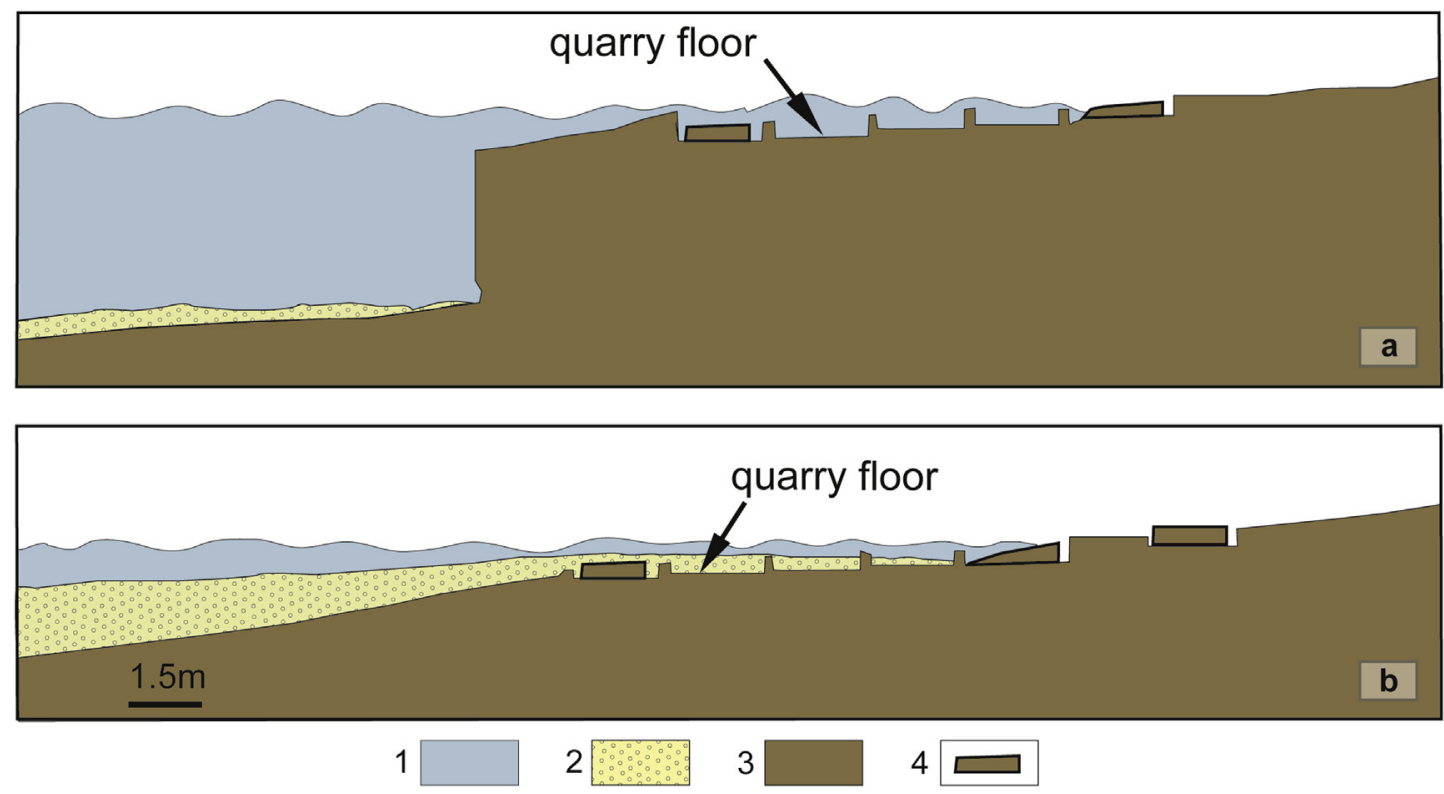

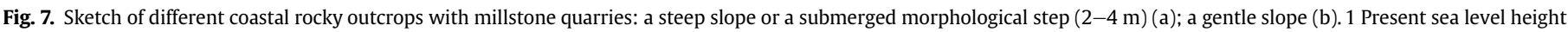
with respect to quarry floor; 2 beach deposit; 3 rocky outcrop and millstone quarry; 4 In situ Millstone.

bench has been shaped during the last phase of the Holocene sea level rise. In this site, submerged and semi-submerged archaeological evidence have been related to the monumental St. Vito Abbey (Favale, 1974; Calderazzi, 1980; Laganara Fabiano, 1981), with various constructional modifications during the XVII century. For that period, historical sources report a mill incorporated in the abbey complex (Andreassi, 1983), for which the nearby millstone quarry could have been settled. This chronological attribution is not certain, as the quarry has been dated to 1400 A.D. (Romano, 2008). The quarried coastal stretch is $20 \mathrm{~m}$ long, with less than 20 millstones carved.

\subsubsection{Calabria}

Soverato quarry (Figs. 1 and 5e) is carved on poorly cemented and coarse sandstones with Clipeaster and locally bioclastic levels of the St. Nicola Formation (Serravallian-Tortonian). The outcrop is often covered by beach sediments and it extends down to about $-10 \mathrm{~m}$. In this coastal area, a tectonic uplift of $0.78 \mathrm{~mm} / \mathrm{y}$ has been estimated (Ferranti et al., 2006, 2010, Table 2). The quarried coastal stretch is $150 \mathrm{~m}$ long with more than 100 millstones carved.

Tropea quarry (Figs. 1 and 6a, b) was carved on well-cemented Miocene sandstones, about 50-60 m thick. The tectonic uplift estimated for this coastal area is about $1.4 \mathrm{~mm} / \mathrm{y}$ (Table 2 ,

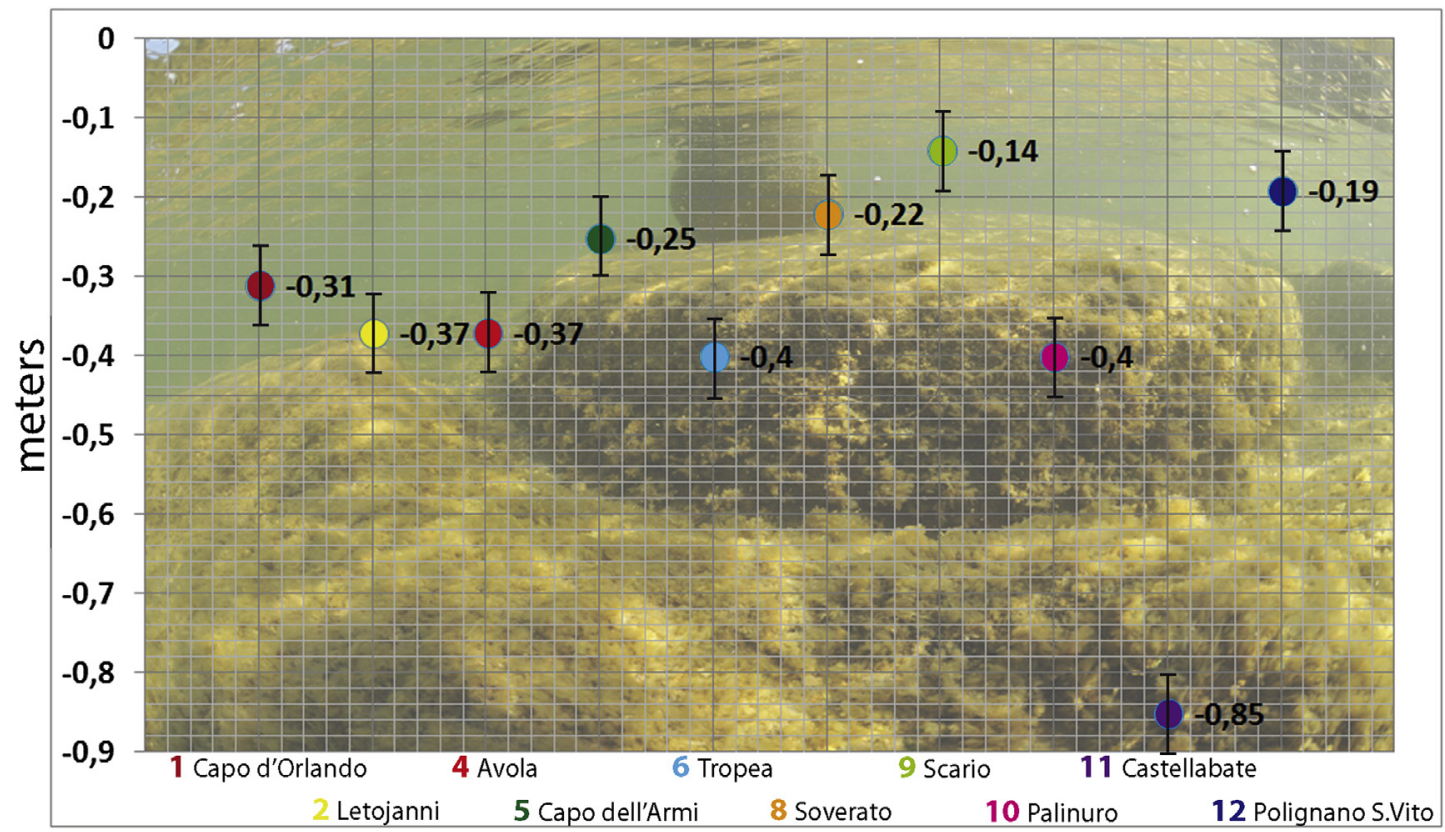

Fig. 8. Elevation asl of the floor of millstone coastal quarries. 
Spampinato et al., in press). The quarried coastal stretch is $40 \mathrm{~m}$ long with less than 50 millstones carved.

Capo Dell'Armi quarry (Figs. 1 and 6c) was carved on well preserved 5 ka beach rock (Scicchitano et al., 2011). This site, known in ancient sources (Thuc. 7, 35; Strabo 6, 259; Cic., ad Att., 16, 7; Phil. 1,3; Plin., Nat. Hist. 3, 6, 73-74; Tabula Peutingeriana), had a strong religious connotation (Giangiulio, 1996; Poccetti, 1996; Chilà, 2002). Archaeological remains from Archaic to Hellenistic periods are present nearby. It is likely that an ancient river mouth would have been used during Roman age as a harbour for small boats, becuase the bay southeast of the cape is identified with the port of ancient Leucopetra (Turano, 1970; Schmiedt, 1975; Costamagna, 1991; Chilà, 2002). Last Interglacial and late Holocene markers suggest comparable uplift rates of about $1 \mathrm{~mm} / \mathrm{y}$ (Scicchitano et al., 2011). The quarried coastal stretch is $100 \mathrm{~m}$ long with less than 50 millstones carved.

\subsubsection{Campania}

Many quarries (Figs. 1 and 6d) have been found along the Castellabate coastal stretch, carved in well-cemented Pleistocene sandstone. Here, there are tens of extraction rings and in situ millstones (Amato, 1983; Agizza, 2009-2010, 2011). According to some authors, millstone extraction along the coastal stretch between Castellabate and Palinuro is attributable to medieval or modern times, between the XV and XVII centuries (De Magistri, 1995). It is probable that millstones were employed in the nearby Tresino S. Giovanni village and in the several mills widespread throughout the region. This area has been considered tectonically stable since the Late Pleistocene (Ferranti et al., 2006). The quarried coastal stretch is about $2 \mathrm{~km}$ long with 3 different sites showing more than 200 millstones carved.

At Palinuro, in the Lido Ficocelle area (Figs. 1 and 6e,f), we found a millstone quarry carved in marine and aeolian deposits related to MIS 5.5 (Brancaccio et al., 1990). The marine deposits (containing Strombus $b$.) unconformably overlie Jurassic carbonate and reach an altitude of $3 \mathrm{~m}$ above sea level, similarly to the tidal notch carved on the limestone promontory of Palinuro (Antonioli et al., 1997). The aeolian deposits show thickness of about $25 \mathrm{~m}$. This area has been considered tectonically stable since the Late Pleistocene (Ferranti et al., 2006). The quarried coastal stretch is about $500 \mathrm{~m}$ long with more than 200 millstones carved.

Scario (Fig. 1) shows several quarries along the coast (Fig. 9a), located in Grotta Grande (Ronchitelli et al., 2011) approximately $2 \mathrm{~m}$ above sea level (Fig. 9b) and on coastal rocky outcrops at sea level (Fig. 9c, d). The most important evidence is the quarry located about $4 \mathrm{~m}$ above sea level, the "Riparo del Molare" (Fig. 9e), which has been preserved by secondary deposits that completely covered it. Millstones were carved on carbonate conglomerate containing Cladocora caespitosa, Spondylus, Ostrea and Strombus bubonius. These deposits reach a thickness of several meters and are attributed to MIS 5.5. This area is considered tectonically stable since the Late Pleistocene (Ferranti et al., 2006). The quarried coastal stretch is $50 \mathrm{~m}$ long with less than 40 millstones carved.

In addition, we did not consider additionally known sites of difficult interpretation, such as Bosa (Oristano, Sardinia, Italy, Fig. 1). This site show the external appearance and morphology similar to the others studied, but the great diversity of these rings with respect to the other studied sites makes it uncertain if this site is a millstone quarry or not. Finally, we observed grain millstones at Filicudi island (Aeolian islands, Sicily, Italy) (Figs. 1 and 2a). The quarry was carved on basaltic rock and is located above sea level, about 3-10 m. Taking into account that millstone diameter and thickness are greater than usual, we have not included the Filicudi quarry in the typology of studied quarries.

\subsection{Chronological estimate for the Scario millstone}

The Scario site has a great scientific relevance for the topic of this paper, with a prehistoric site dated to the Middle Paleolithic (100-70 ka: MIS 5d/a-early MIS 4) called "Riparo del Molare" (Ronchitelli, 1993, Fig. 9e, f). Research (1984-2001) of the prehistoric deposits (Ronchitelli, 1993) allowed the discovery of a millstone quarry and important archaeological remains of the time of carving activities (Ronchitelli, 1993; Ronchitelli et al., 2010). During the Middle Paleolithic, Neanderthals occupied the same shelter-site which became a millstone quarry in the Modern age. At this site, some millstones (broken or defective) as well as numerous rings indicating complete extractions are still preserved in situ. This evidence remained intact because the quarry is $4 \mathrm{~m}$ above sea level and millstones had been totally covered by sediment derived from the overlying slope (Fig. 9f). Meaningful remains annexed to the millstone quarry have been found in the layer of abandonment, which marks the last phase of quarrying activity and covers directly the millstones (Fig. 10): a wrought iron wedge (Fig. 9g) used as carving tool, dated by metallurgical analysis to a period between 1500 and 1784 A.D. (Wayman M.L. Dept. Of Mining, Metallurgical and Petroleum Engineering, University of Albert, personal communication, 1991); two conical basins of monochrome lead glazed ware (Tagliente, 2005; Fig. 9h) attributable to late Medieval and post-Medieval age; fragments of tin glazed ware (plates), dated at the XVI century A.D.; and fragments of incised coarse ware, used during the late Renaissance period (XVI-XVII century A.D.; Güll, 2008) (Fig. 9i).

In addition, in the same layer fire carbonized wood remains (Ronchitelli, 1993) were found. Two radiocarbon analysis (UtC1341) on these charcoal samples indicate the age of quarry exploitation at 1528-1555 A.D. and 1632-1657 A.D., respectively (Ronchitelli, 1993) The second interval is more compatible with data from ceramic artifact analysis and coincides with the date, 1632 A.D., incised on a millstone located in the village of Capitello, between Scario and Sapri, and carved in Riparo Molare (courtesy of Giovanni d'Andrea). For dating the age of quarry activation, we used $1645 \pm 11$ ka (mean of 1632-1657).

\section{Discussion}

Cylindrical millstones with a diameter larger than one meter may be related to both olive oil squeezing, from Roman time until modern ages, and grain-grinding in modern times. The archaeological ages (from XVII to XIX century) of millstones larger than 1.10-1.30 $\mathrm{m}$ for grain grinding were also established in Spain and French (Anderson and Scarrow, 2011). The lithological features of quarried rocks allow us to discriminate two types: millstone for cereals are normally carved on volcanic rocks, while those for oil production are carved on limestone, conglomerates, sandstones and beach-rocks. Scicchitano et al. (2011) described and discussed two partially submerged millstone quarries located in the coastal sites of Capo dell'Armi and Capo d'Orlando, chronologically referred to a period between 1.0 and 2.4 ka depending on the considered uplift rate. This chronological attribution, in absence of additional robust archaeological sea level indicators, was based on the estimate of regional tectonic uplift-rates and measurement of the elevation (with respect to the mean sea level) of the submerged portion of the quarry floor, assuming that the millstones were carved in a dry environment. Conversely, for the archaeological sites of Scario analyzed in this paper, it was possible, for the first time in the central Mediterranean area, to provide an accurate chronological attribution of millstone quarry using both ceramics and radiocarbon dating. 

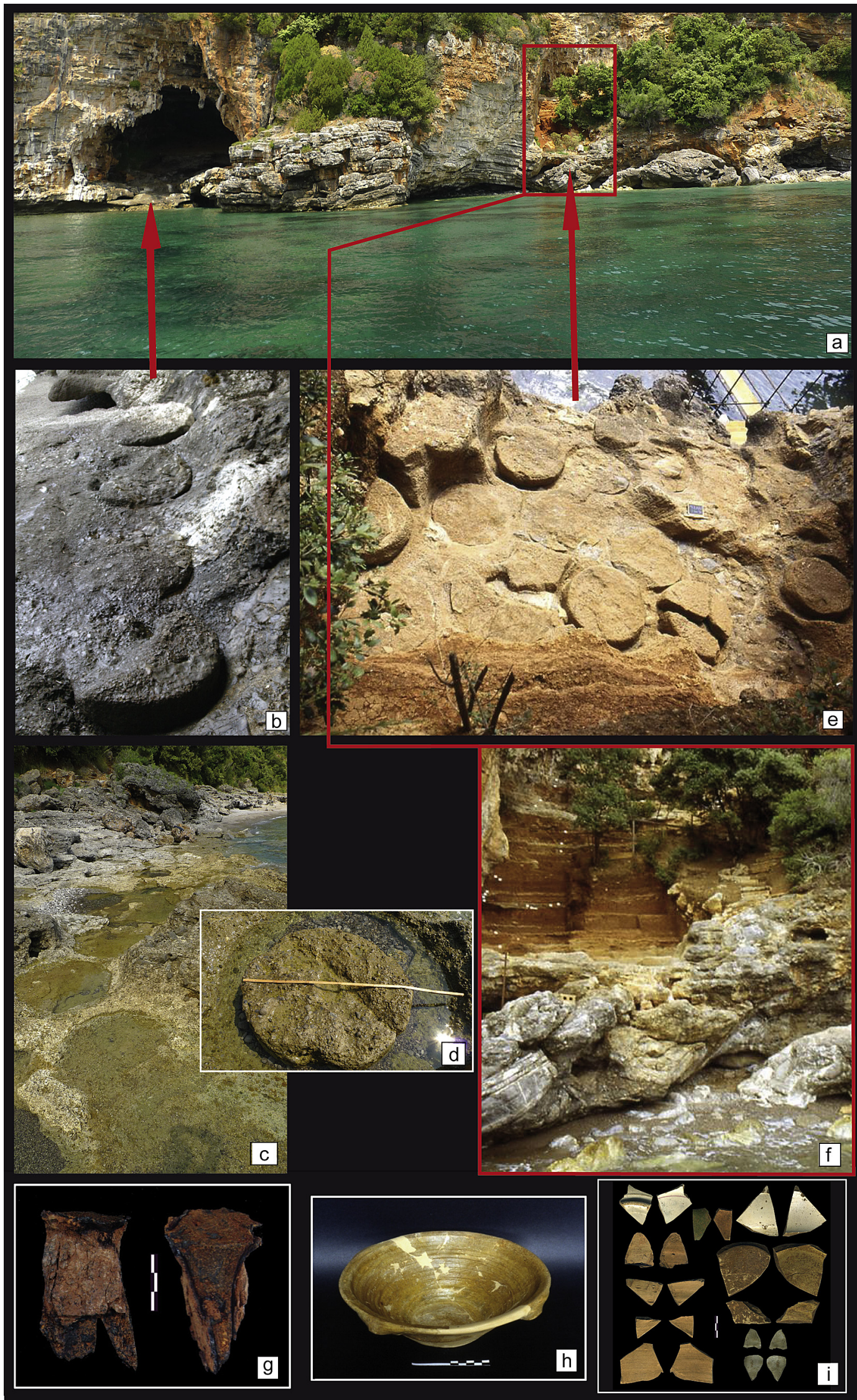

Fig. 9. Scario site, panoramic view (a) of the millstone quarry. View inside the Grotta Grande (b) at $2 \mathrm{~m}$ above sea level, along the coast (c, d) and at the "Riparo Molare" quarry (e). Prehistoric deposit of Riparo del Molare (Middle Paleolithic, Fig. 10) (f). Iron wedge of 1500-1784 (g), glazed ceramic of low-medieval and post-medieval age (h), fragments of enamel plates of XVI century (i), found during archaeological excavation carried out under the direction of A. Ronchitelli. 


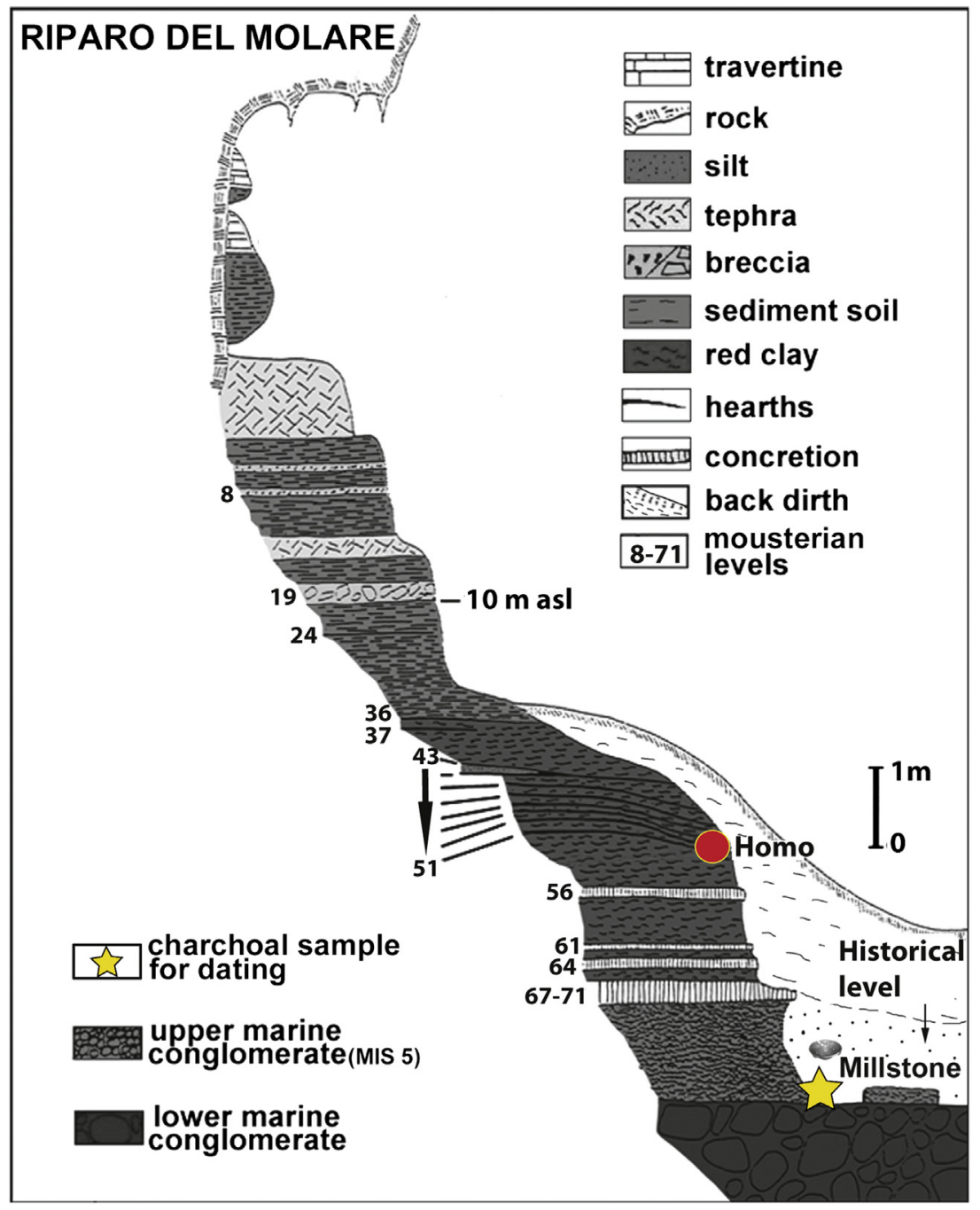

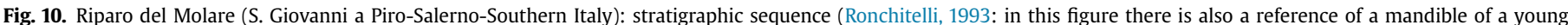
Neanderthal-men. Mallegni and Ronchitelli, 1987a,b).

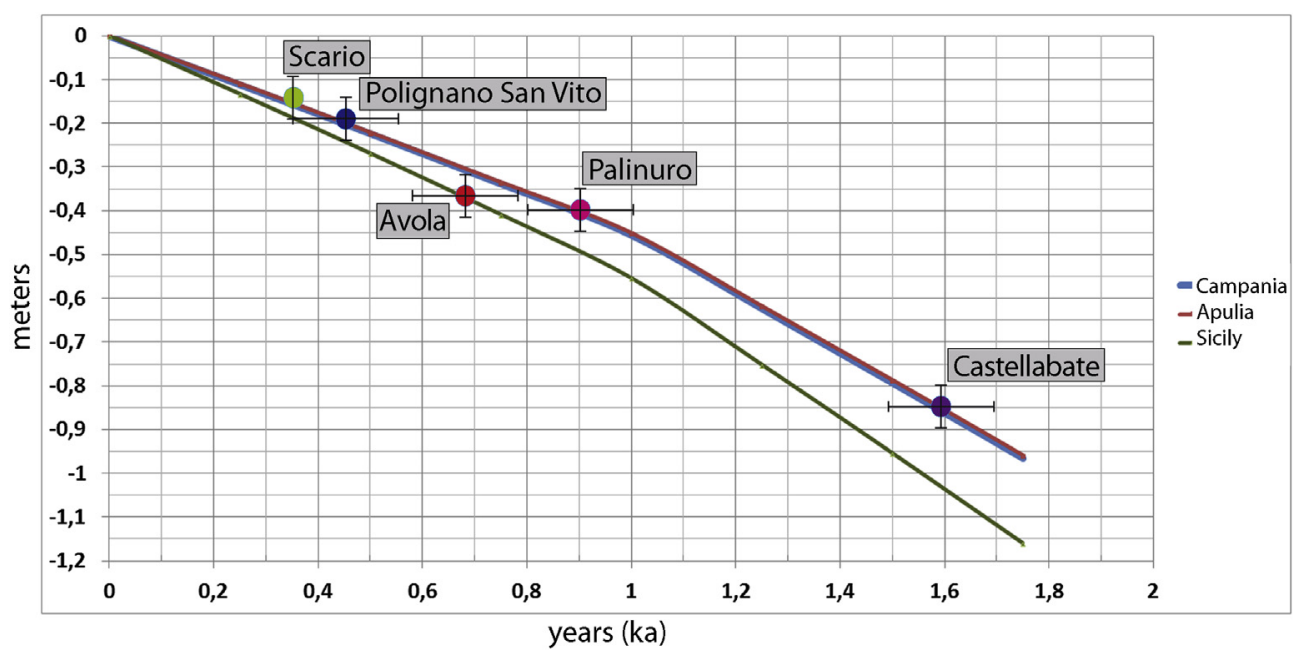

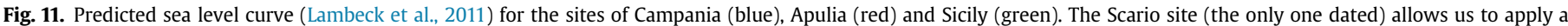

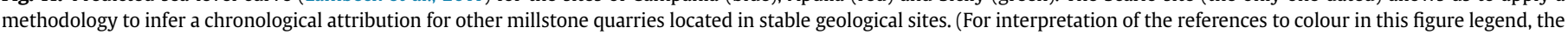
reader is referred to the web version of this article.) 
In addition, because Scario is located in a geologically stable area (Table 2) we can tentatively assume this site as a reference in order to give an age for the other coastal millstone sites. Using 1) the Holocene sea level prediction (Lambeck et al., 2011); 2) the age of the quarry; and 3) the tidal corrected present elevation of the Scario's millstone $(-14.8 \mathrm{~cm})$, we tentatively determined the sealevel position at the time when it was carved.

Fig. 10 reports these values. The vertical axis (Table 2) shows the quarry plans at $-14.8 \mathrm{~cm}$. The horizontal axis shows the age of the final exploitation phase at $1645 \pm 11 \mathrm{ka}$, active until about $368 \mathrm{BP}$. The point obtained from the intersection of the two values falls on the predicted sea level curve (Fig. 11). Millstone quarries are very limited along the Italian coast: according to morphological evidence, we therefore assume that millstones for olive oil were extracted at the sea level. This indicates that, for this type of quarry, the "functional elevation" is close to the past mean sea level. Archaeological information suggests that the wheels were transported by small boats up to exhaustion of the available stones. Conversely, for quarries with longer cultivation time periods and greater stone height, the functional height is considered to be within 0.3 and $0.6 \mathrm{~m}$ (Lambeck et al., 2004).

As regards the age estimated for the other geologically stable sites (Polignano San Vito, Palinuro, Avola and Castellabate), we used the sea level prediction of Lambeck et al. (2011), by comparing the reference curves (Fig. 11) with the depth of each quarry plan, so that the point falls $1-2 \mathrm{~cm}$ above the curve according to the model developed for the Scario quarry. This allows us to tentatively pick, on the horizontal axis, the age of individual quarries. We added an error bar of \pm 100 years, to take in account the measurement error.

Besides Scario, two additional sites are found in the Campania region. The Palinuro quarry shows a quarry floor at a depth of $-40 \mathrm{~cm}$ (Tables 1 and 2), and, when compared against the sea level prediction, it can be tentatively dated to the Middle Ages (mean age attribution: $1113 \pm 100$ A.D.). The Castellabate site, having a quarry floor at altitude depth of $-85.5 \mathrm{~cm}$, should be dated to the late Roman period (mean age: $423 \pm 100$ A.D.).

The Polignano San Vito quarry floor, falls on the predicted curve for Apulia (which is virtually coincident with the predicted curve for Campania), at the depth of $-19.5 \mathrm{~cm}$, very close to those of Scario site, and therefore can be tentatively dated to $1553 \pm 100$ A.D. The Avola quarry, which stands on the predicted curve for Sicily, has a floor at $-37 \mathrm{~cm}$ depth, and thus can be dated to the late Middle Age (mean age: $1333 \pm 100$ A.D.).

Our chronological attributions (Table 3 ) indicate a relatively recent period of extraction from the Latest Roman (the Castellabate quarry), the Middle Age, to the seventeenth century (the Scario quarry). Even though the archeological literature proposes millstone quarries from the Greek period (2.4 ka BP) and throughout the Roman period (2.1-1.8 ka BP), we found no evidence on the coast of southern Italy of older and/or deeper quarries. Considering that the sea level predicted by the model of Lambeck et al. (2011) along the Tyrrhenian Sea coast between 2.4 and $2 \mathrm{ka}$ BP is from -1.7 to $-1.1 \mathrm{~m}$, we hypothesize that older quarries, although they are well documented throughout Europe but are completely absent in the central Mediterranean, were destroyed by erosion or are buried by sediments.

Table 3

Timing and duration of the Millstone quarry comparing A.D with BP age. Roman Age: 2200-1537 BP, Middle age 1537-500 BP, Modern Age: 500-Present.

\begin{tabular}{llcc}
\hline Site no. & Location & Age A.D. & Age BP \\
\hline 9 & Scario & 1645 & 368 \\
12 & Polignano & 1553 & 460 \\
4 & Avola & 1333 & 680 \\
10 & Palinuro & 1113 & 900 \\
11 & Castellabate & 423 & 1590 \\
\hline
\end{tabular}

The future preservation of these archaeological sites is problematic. Erosion rates of the rock and sea wave action determine the progressive thickness decrease of millstones, as shown in Fig. 9b.

As regard the tectonically unstable sites, if we apply the local uplift rate reported by previous works (Table 2) we obtain values in disagreement with those calculated for stable areas. For example, if we apply uplift rates at Capo dell'Armi and Tropea sites (respectively $1 \mathrm{~mm} / \mathrm{y}$ and $0.67 \mathrm{~mm} / \mathrm{y}$ ), the calculated ages of the quarries are about 6 and $3.5 \mathrm{ka}$ BP (Fig. 12), older than the use of oil mills around the Mediterranean Sea. In these areas (Ionian and Tyrrhenian Calabria, North-eastern Sicily) tectonic uplift shows both regional and coseismic components (Ferranti et al., 2007, 2010; Spampinato et al., 2012; Anzidei et al., 2013). In addition, the late Holocene tectonic rates generally show higher values than those calculated using the last Interglacial marker (Antonioli et al., 2006; Ferranti et al., 2007). This probably means that as a result of coseismic rapid movements with quiescence periods, the estimate based on the present altitude of the millstone quarries' floors may be unrealistic when compared with stable areas. If we do not consider the tectonic corrections and compare the depth values with the predicted curve (as done for the stable sites), we obtain an
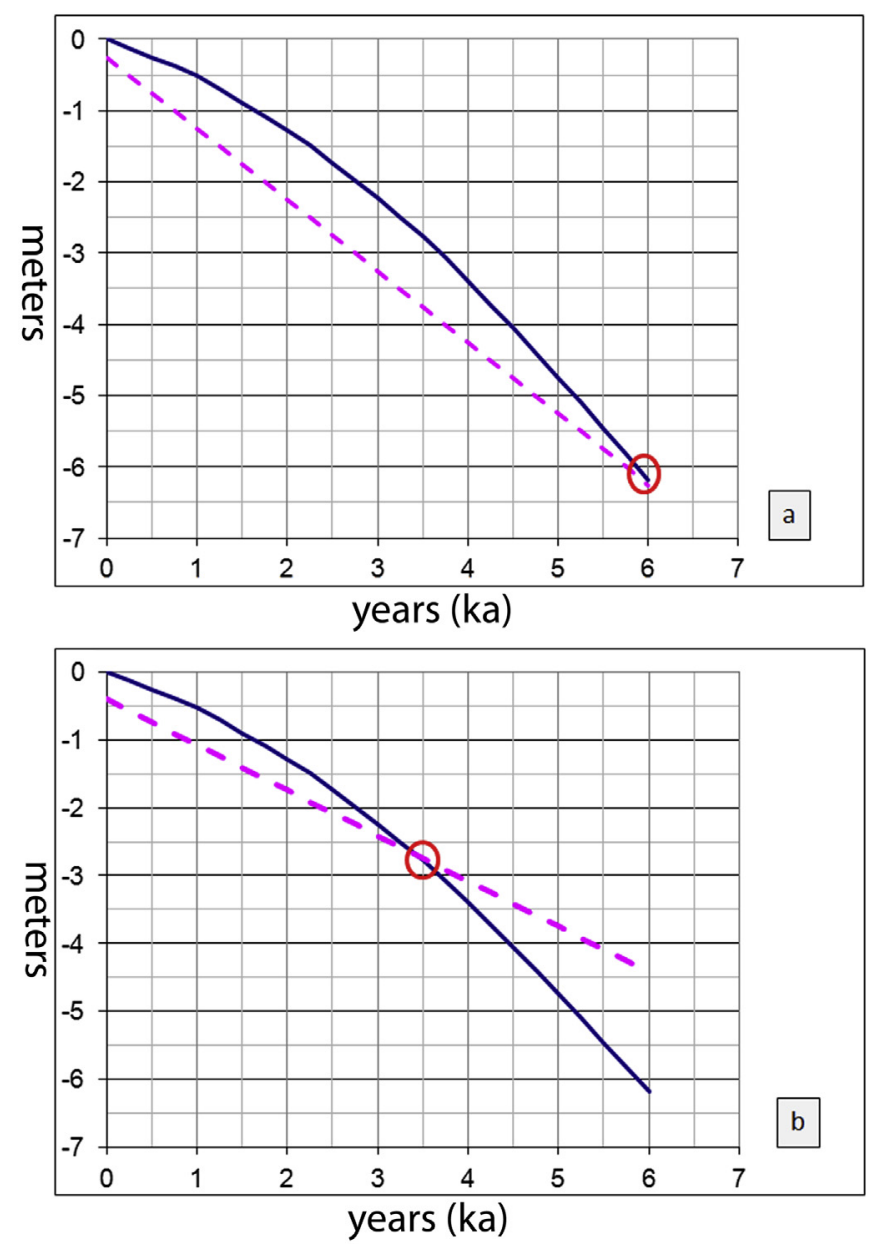

Fig. 12. Example of age calculation for two tectonically unstable sites: Capo dell'Armi (a) and Tropea (b). Pink and dashed line: uplift rates: $1 \mathrm{~mm} / \mathrm{y}$ and $0.67 \mathrm{~mm} / \mathrm{y}$ respectively; blue and continuous line: sea level curve according to Lambeck et al. (2011). The intersection of the two line shows the age of the quarries: 6 and $3.5 \mathrm{ka} \mathrm{BP}$. (For interpretation of the references to colour in this figure legend, the reader is referred to the web version of this article.) 


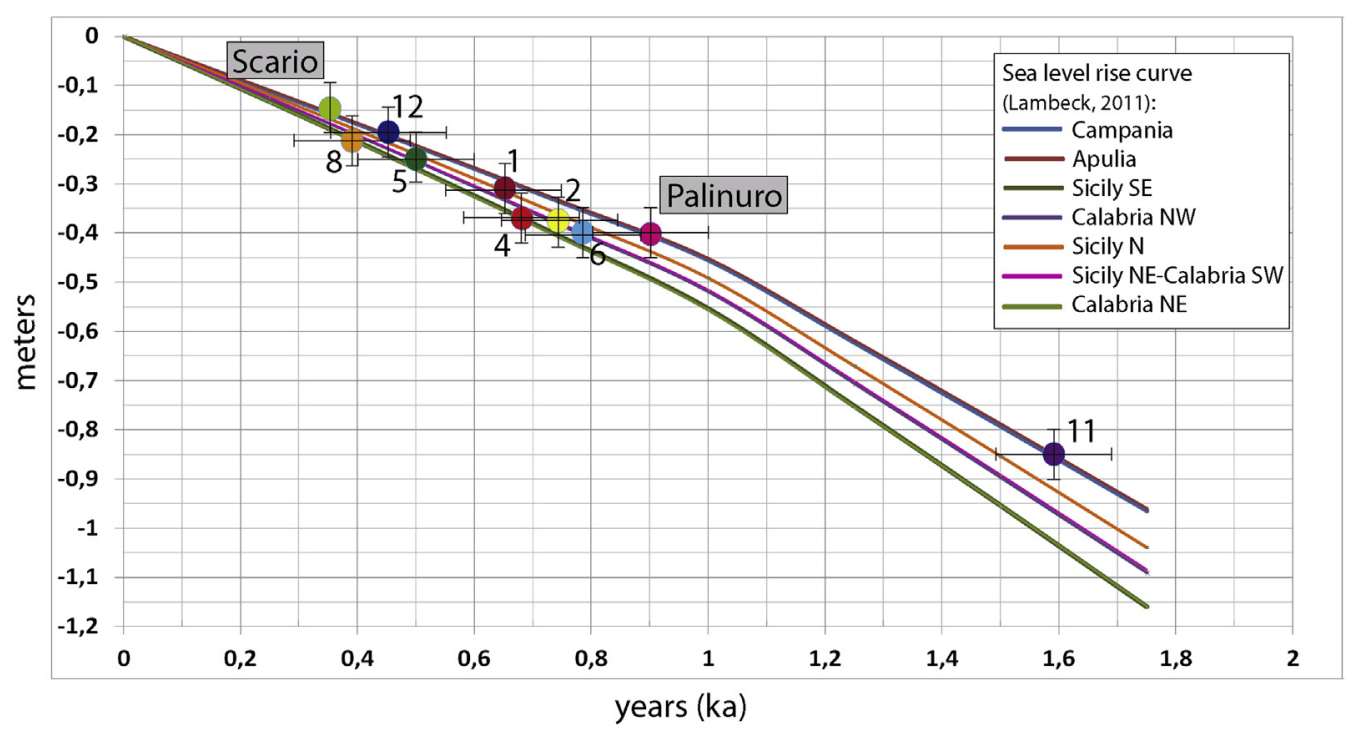

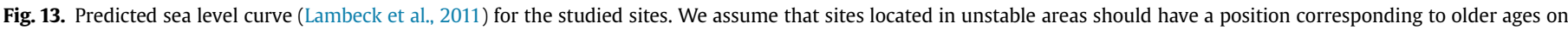

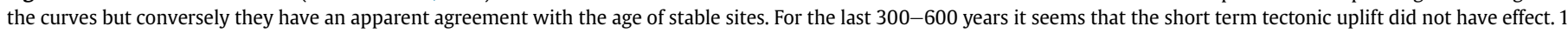
Capo d'Orlando; 2 Letojanni; 4 Avola; 5 Capo dell'Armi; 6 Tropea; 8 Soverato; 11 Castellabate; 12 Polignano.

apparent agreement (Fig. 13). For the last 300-600 years, tectonic uplift did not have an effect.

From features and elevation of the investigated quarries, we have estimated the age of their use in the time window 1590360 BP (423 A.D.-1645 A.D.). During this time-range, two climatic variations are known: the Medieval Warm Period (MPW, 9001300 A.D.) and the Little Ice Age (LIA, 1600-1850 A.D.) Unfortunately, no observational evidence on sea level changes which can be addressed to the LIA is known from the Mediterranean. Toker et al., 2011, from archaeological indicators of the Crusader period located along the coast of Israel, found a sea level fall at $50 \pm 20 \mathrm{~cm}$ during the MPW.

From geological records, during cold periods sea level sometimes decreases. If sea level was falling during the lower temperature phase of LIA, the functional elevation of millstone quarries carved during the time windows 900-1300 A.D. and 16001850 A.D. was limited to a few decimeters above mean sea level. Although we cannot provide a precise functional elevation of these quarries in absence of additional constraints, it is reasonable to assume that millstones were carved close to sea level and above high tide to retain a safety margin.

\section{Conclusions}

From the study of 10 millstone quarries, the main results achieved in this work are summarized as follows:

1) 10 sites of olive oil millstone quarries in southern Italy have been studied and measured following a standard methodology, and the geological and archaeological features were investigated;

2) most of the quarries were carved on beach rocks or limestones, characterized by a plan ending seaward up to $3-5 \mathrm{~m}$ high underwater cliffs or with a nearby beach that allowed landing of small ships or barges, used to transport the carved millstones.

3 ) from the chronological data of Scario site, we estimated the age of activities of millstone quarry: A.D. $1645 \pm 11$; $368 \mathrm{BP}$;

4) from archaeological evidence and the elevation of the Scario site, compared against the predicted sea-level for the late Holocene, we tentatively estimated the functional elevation of the other millstone quarries by similarity. This value is close to zero, if during LIA sea level did not change significantly. In this case, millstones were carved at sea level. Conversely, if during LIA sea level was little lower than today, functional elevations were slightly above the mean sea level;

5 ) based on the chronological attribution of the Scario site and plotting on modeled sea level curves, it was possible to infer the mean age of Polignano San Vito, Palinuro, Avola, and Castellabate quarries, all located in tectonically stable areas, with ages ranging between 1590 and $368 \mathrm{BP}$.

We can inferred that the millstone quarries may represent a new relative sea level indicator being carved along the rocky shores of the Mediterranean sea close to the shoreline position at the time they were carved, even if a lack of archaeological and historical data limits the definition of their chronology.

\section{Acknowledgements}

We thank the Soprintendenza per i Beni Archeologici di Salerno, Avellino, Benevento, and Caserta, which authorized and supported the excavations at Masseta di Scario over the years; the Soprintendenza per i Beni Archeologici di Calabria and Dr. Iannelli for the measurements at Soverato; and all the colleagues, students and friends, who took part in the field archaeological research, for their enthusiastic collaboration.

\section{References}

Acquaviva, R., 1995. Palmenti e frantoi in Sicilia, in particolare nell'area dei monti Iblei. Lavoro e tecnica dall'antichita ai nostri giorni, Siracusa.

Agizza, S., 2009-2010. Carta archeologica del territorio di Castellabate. Tesi Specializzazione. Università degli Studi del Salento.

Agizza, S., 2011. Marine Protected Area of S. Maria di Castellabate and the archaeological "site" of Licosa. In: Cascalheira, J., Gonçalves, C. (Eds.), Actas das IV Jornadas de Jovens in Investigação Arqueológica - JIA 2011 (Faro, 11-14 maio 2011), Promontora Monográfica 16, Faro, pp. 65-71.

Amato, A.R., 1983. Eccezionale scoperta in S. Maria di Castellabate - La Cava dei Rocchi. Cilen-to nuovo, 7/8: 3.

Amouretti, M.C., 1986. Le pain et l'huile dans la Grèce antique. Paris.

Amouretti, M.C., 2002. Découvertes archéologiques récentes sur le moulins et pressoirs romains de Provence. In: Rivet, L., Sciallano, M. (Eds.), Vivre, produire 
et échanger : Reflets méditer-ranéens. Mélanges offerts à Bernard Liou (Arch. et Hist. Rom., 8), Montagnac, pp. 465-469.

Amouretti, M.C., Brun, J.P., 1993. La production du vin et de l'huile en Méditerranée. BCH suppl. 26, Athens.

Amouretti, M.C., Brun, J.P., 2002. Olivier et huile dans l'Antiquité: decouvertes archéologiques récentes. In: Amouretti, M.C., Comet, G. (Eds.), Agriculture méditerranéenne. Variété des techniques anciennes, pp. 127-141. Aix-enProvence.

Amouretti, M.C., Comet, G., Ney, C., Paillet, J.-L., 1984. À propos du pressoir à huile: de l'archéologie industrielle à l'histoire. MEFRA 96 (1), 379-421.

Anderson, T., Scarrow, J.H., 2011. Millstone quarries in southern Spain: preliminary pinpointing of provenance and production - exploiting the internet. In: Williams, D., Peacock, D. (Eds.), Bread for the People. The Archaeology of Mills and Milling. Proceedings of a Colloquium Held in the British School at Rome 4th-7th November 2009, British Archaeological Research International Series. 2274, pp. 259-275. Oxford.

Andreassi, G., 1983. Sopravvivenze dell'antico. In: Labbate, V. (Ed.), Il territorio a sud-est di Bari in età medievale. Società e ambienti, Conversano, pp. 37-42.

Antonioli, F., Cinque, A., Ferranti, L., Romano, P., 1997. Emerged and submerged quaternary marine terraces of palinuro cape (Southern Italy). Memorie Descrittive del Servizio Geologico Nazionale 52, 237-260.

Antonioli, F., Ferranti, L., Lambeck, K., Kershaw, S., Verrubbi, V., Dai Pra, G., 2006 Late Pleistocene to Holocene record of changing uplift rates in southern Calabria and eastern Sicily (southern Italy, Central Mediterranean Sea). Tectonophysics 422, 23-40.

Antonioli, F., Anzidei, M., Lambeck, K., Auriemma, R., Gaddi, D., Furlani, S., Orrù, P. Solinas, E., Gaspari, A., Karinja, S., Kovačič, V., Surace, L., 2007. Sea level change during the Holocene in Sardinia and in the North-eastern Adriatic (Central Mediterranean sea) from archaeological and geomorphological data. Quaternary Science Reviews 26, 2463-2486.

Antonioli, F., Ferranti, L., Fontana, A., Amorosi, A.M., Bondesan, A., Braitenberg, C., Dutton, A., Fontolan, G., Furlani, S., Lambeck, K., Mastronuzzi, G., Monaco, C. Spada, G., Stocchi, P., 2009. Holocene relative sea-level changes and vertical movements along the Italian coastline. Quaternary International 206, 102-133.

Anzidei, M., Antonioli, F., Lambeck, K., Benini, A., Soussi, M., 2011a. New insights on the relative sea level change during Holocene along the coasts of Tunisia and western Libya from archaeological and geomorphological markers. Quaternary International 232, 5-12.

Anzidei, M., Antonioli, F., Benini, A., Lambeck, K., Sivan, D., Serpelloni, E., Stocchi, P. 2011b. Sea level change and vertical land movements since the last two millennia along the coasts of southwestern Turkey and Israel. Quaternary International 232, 13-20.

Anzidei, M., Fabrizio Antonioli, F., Alessandra Benini, A., Anna Gervasi, A., Ignazio Guerra, I., 2013. Evidence of vertical tectonic uplift at Briatico (Calabria, Italy) inferred from Roman age maritime archaeological indicators. Quaternary International 288, 158-167.

Auriemma, R., Solinas, E., 2009. Archaeological remains as sea level change markers: a review. Quaternary International 206, 134-146.

Bell, M., 1994. An Imperial Flour Mill on the Ja-niculum. In: Le Ravitaillement en blé de Rome et des centres urbains des débuts de la Répub-lique jusqu'au HautEmpire, Actes du colloque international (Naples, 14-16 Février 1991), Publications de l'École française de Rome, 196, Rome, pp. 73-89.

Belmont, A., 2006a. Atlas des carrières de meules de moulins en Europe. http:// meuliere.ish-lyon.cnrs.fr/.

Belmont, A., 2006b. Les meulières médiévales. Résultats d'une moisson dauphinoise. In: Belmont, Mangartz 2006, pp. 81-90.

Belmont, A., 2011. Why dig a millstone quarry? The case of Claix in the South West of France (5th-19th centuries). In: Williams, D., Peacock, D. (Eds.), Bread for the People. The Archaeology of Mills and Milling. Proceedings of a Colloquium Held in the British School at Rome 4th-7th November 2009, British Archaeological Research International Series. 2274, pp. 1-17. Oxford.

Belmont, A. Mangartz, F. (Eds.), 2006. Millstone quarries. Research, Protection and Valorization of an European Industrial Heritage (Antiquity-21th Century), In ternational Colloquium (Grenoble, 22th-25th of September 2005), Mainz.

Benoit, F. 1940. L'usine de meunerie hydraulique de Barbegal. Revue Archéologique 15 (1940-1945), 19-80.

Bessac, J.C., 1986. La prospection archéologique des carrières de pierre de taille: approche méthodologique. Aquitania 4, 151-171.

Boardman, J., 1958-1959. Excavations at Pindakas in Chios. The Annals of the British School at Athens 53-54, 301-308.

Bonanno, C., 2004. Le necropoli. In: Spigo, U. (Ed.), Archeologia a Capo d'Orlando. Studi per l'Antiquarium, Milazzo (Me), pp. 79-90.

Bonardi, G., Giunta, G., Perrone, V., Russo, M., Zuppetta, A., Ciampo, G., 1980. Osservazioni sull'evoluzione dell'arco Calabro-Peloritano nel Miocene inf::la formazione di Stilo-Capo d'Orlando. Bollettino Società Geologica Italiana 98 365-393.

Brancaccio, L., Cinque, A., Romano, P., Rosskopopf, C., Russo, F., Santangelo, N., Santo, A., 1990. Geomorphology and neotectonic evolution of a Sector of the Tyrrhenian flank of the Southern Apennines (Region of Naples, Italy). Zeitschrift fur Geomorphologie, N.F (Suppl. 82), 47-58.

Brun, J.P., 1997. L'introduction des moulins dans les huileries antiques. In: Garcia, D., Meeks, D. (Eds.), Techniques et économie antiques et médiévales. Le temps de l'innovation, Colloque d'Aix-en-Provence (mai 1996), Paris, pp. 69-78.

Brun, J.P., 2004. Archéologie du vin et de l'huile. De la préhistoire à l'époque hellénistique, Paris.
Busana, M.S., D’Incà, C., Forti, S., 2009. Olio e pesce in epoca romana nell'alto e medio Adriatico. In: Pesavento Mattioli, S., Carre, M.B. (Eds.), Olio e pesce in epoca romana: produzione e commercio nelle regioni dell'Alto Adriatico. Atti del Convegno (Padova, 16 febbraio 2007), Roma, pp. 37-81.

Calderazzi, A., 1980. Masseria-convento fortificata a S. Vito di Polignano, Castella 20. Studi castellani in onore di Pietro Gazzola, 2, Roma, pp. 249-264.

Carandini, A., 1985. Settefinestre. Una villa schiavistica nell'Etruria Romana. In: La villa nelle sue parti, Modena, vol. II.

Carbone, S., Lentini, F., Vinci, G., 1998. Carta geologica del settore occidentale dei Monti Peloritani (Sicilia nord-orientale). S.EL.CA., Firenze.

Chilà, D.M., 2002. Il versante orientale dello Stretto di Messina: Rhegium, il suo porto e il sistema di approdi viciniori. In: Gentili, B., Pinzone, A. (Eds.), Messina e Reggio nell'antichità: storia, società e cultura. Atti del Convegno della S.I.S.A.C. (Messina-Reggio Calabria 24-26/5/1999), Pelorias, 9, pp. 441-454.

Ciaranfi, N., Pieri, P., Ricchetti, G., 1988. Note alla carta geologica delle Murge e del Salento (Puglia centromeridionale), 1:250.000. Memorie della Società Geologica Italiana 42, 449-460.

Costamagna, L., 1991. La sinagoga di Bova Marina nel quadro degli insediamenti tardoantichi della costa Ionica meridionale della Calabria. Mélanges de l’École Française de Rome Moyen Age 103 (2), 611-620.

De Magistri, E., 1995. Il mare di Elea. In: Tra Lazio e Campania. Ricerche di Storia e Topografia antica, «Università degli Studi di Salerno, Quaderni del Dipartimento di Scienze dell' Antichità» 16, pp. 7-77.

Di Grande, A., Raimondo, W., 1982. Linee di costa plio-pleistoceniche e schema litostratigrafico del Quaternario siracusano. Geologica Romana 21, 279-309.

Dworakowska, A., 1975. Quarries in Ancient Greece. Academia Scientarum Polonia, Warszawa.

D’Alessandro, A., Iannone, A., 1984. Prime considerazioni sedimentologiche e paleoecologiche su alcune sezioni della Calcarenite di Gravina (Pleistocene) nei pressi di Monopoli. Studi di Geologia e Geofisica 27, 1-16.

Faccenna, D., 1957. Tivoli (Località Granaraccio): resti della parte rustica di una villa. Notizie Scavi Antichità, pp. 148-152.

Favale, D., 1974. Polignano a mare. Centro di Ricerche storico-artistiche speleoarcheologiche di Polignano a mare, Bari.

Felici, E., Lanteri, L., 2012. Latomie costiere a Siracusa. Tradizione, tecnologia e territorio $1,57-80$.

Felici Buscemi, G., Felici, E., 2004. Latomie costiere tra Punta Castelluzzo e Brucoli (Augusta). Daidalos 6, 159-188.

Ferranti, L., Antonioli, F., Mauz, B., Amorosi, A., Dai Pra, G., Mastronuzzi, G., Monaco, C., Orrù, P., Pappalardo, M., Radtke, U., Renda, P., Romano, P., Sansò, P., Verrubbi, V., 2006. Markers of the last interglacial sea level highstand along the coast of Italy: tectonic implications. Quaternary International 145-146, 30-54.

Ferranti, L., Monaco, C., Antonioli, F., Maschio, L., Kershaw, S., Verrubbi, V., 2007. The contribution of regional uplift and coseismic slip to the vertical crustal motion in the Messina Straits, Southern Italy: evidence from raised Late Holocene shorelines. Journal of Geophysical Research 112, B06401.

Ferranti, L., Antonioli, F., Anzidei, M., Monaco, C., Stocchi, P., 2010. The timescale and spatial extent of vertical tectonic motions in Italy: insights from relative sealevel changes studies. Journal of the Virtual Explorer. http://dx.doi.org/ 10.3809/jvirtex.2009.00255.

Flemming, N.C., 1969. Archaeological evidence for eustatic changes of Sea level and Earth movements in the western Mediterranean in the last 2000 years. Geological Society of America Special Paper 109, 1-125.

Foxhall, L., 1993. Oil extraction and processing equipment in classical Greece. In: Amouretti, M.C., Brun, J.P. (Eds.), La production du vin et de l'huile en Méditerranée, pp. 183-199. BCH suppl. 26, Athens.

Frankel, R., 1993. The trapetum and mola olearia. In: Amouretti, M.C., Brun, J.P. (Eds.), La production du vin et de l'huile en Méditerranée, pp. 477-481. BCH suppl. 26, Athens.

Furlani, S., Cucchi, F., Forti, F., Rossi, A., 2009. Comparison between coastal and inland Karst limestone lowering rates in the northeastern Adriatic Region (Italy and Croatia). Geomorphology 104, 73-81.

Gateau, F., 1997. L'établissement rural de La Pousaraque (Gignac-la-Nerthe, Bouches-du-Rhône). Oléiculture en Basse-Provence. Revue Archéologique de Narbonnaise 30, 5-26.

Geist, H., 2003. Une carrière de meules sur le rivage de Cap d'Ail. In: Barboff, M., Sigaut, F., Griffin, C., Kremer, R. (Eds.), Meules à grains. Actes du colloque international (La Ferté-sous-Jouarre, 16-19 mai 2002), Paris, pp. 218-230.

Giangiulio, M., 1996. Tra mare e terra. L'orizzonte religioso del paesaggio costiero. In: Prontera, F. (Ed.), La Magna Grecia e il mare. Studi di storia marittima, Taranto, pp. 251-272.

Glicksman, K., 2007. Olive and wine cultivation in the Roman province of Dalmatia. Histria Antiqua 15, 43-50.

Güll, P., 2008. Lo scavo degli ambienti CXXXIV-CXL. In: Güll, P. (Ed.), Roca nel Basso Medioevo. Strutture abitative e cultura materiale di un centro urbano dell'Adriatico meridionale (scavi 2005), AMediev 35, pp. 381-426.

Hadjisavvas, S., 1992. Olive Oil Processing in Cyprus from the Bronze Age to the Byzantine Period. In: Studies in Mediterranean Archaeology, vol. 99. Nicosia.

Humphrey, J.W., Oleson, J.P., Sherwood, A.N., 2006. Greek and Roman Technology: a Sourcebook, second ed. Routledge, London-New York.

Iannone, A., Pieri, P., 1979. Considerazioni critiche sui "Tufi calcarei" delle Murge. Nuovi datii litostratigrafici e paleoambientali. Geografia Fisica e Dinamica Quaternaria 2, 173-186.

Jaccottey, L., 2011. Seven thousand years of millstone production in the Serre Mountain Range of the French Jura. In: Williams, D., Peacock, D. (Eds.), Bread for 
the People. The Archaeology of Mills and Milling. Proceedings of a Colloquium Held in the British School at Rome 4th-7th November 2009, British Archaeological Research International Series. 2274, pp. 293-307. Oxford.

Kloner, A., Sagiv, N., 1993. The olive presses of hellenistic Maresha, Israel. In: Amouretti, M.C., Brun, J.P. (Eds.), La production du vin et de l'huile en Méditerranée, pp. 119-136. BCH suppl. 26, Athens.

Kozelj, T., Wurch Kozelj, M., 1993. Les transports dans l'Antiquité. In: Francovich, R. (Ed.), Archeologia delle attività estrattive e metallurgiche. V Ciclo di Lezioni sulla Ricerca applicata in Archeologia (Certosa di Pontignano (SI) e Campiglia Marittima (LI), 9-21 settembre 1991), Firenze, pp. 97-142.

Laganara Fabiano, C.A.M., 1981. Abbazia di S. Vito. Polignano. In: Calò Mariani, M. (Ed.), Insediamenti benedettini in Puglia, 2 (primo tomo), Galatina, pp. 237248.

Lambeck, K., Anzidei, M., Antonioli, F., Benini, A., Esposito, A., 2004. Sea level in Roman time in the Central Mediterranean and implications for recent change. Earth and Planetary Science Letters 224 (3-4), 563-575.

Lambeck, K., Antonioli, F., Anzidei, M., Ferranti, L., Leoni, G., Silenzi, S., Scicchitano, G., Silenzi, S., 2011. Sea level change along the Italian coast during the Holocene and projections for the future. Quaternary International 232, $250-257$.

Lohmann, H., 1993. Ein Turmgehöft klassischer Zeit in Thimari (Südattika). Athenische Mitteilungen 108, 101-149.

Maffei, A., Nastasi, F. (Eds.), 1990. Caere e il suo territorio da Agylla a Centumcellae, Roma.

Mallegni, F., Ronchitelli, A., 1987a. Découverte d'une mandibule néanderthalienne à l'Abri du Molare près de Scario (Salerno, Italie): observations stratigraphiques et palethnologiques, étude anthropologique. L'Anthropologie 91 (1), 163-174.

Mallegni, F., Ronchitelli, A., 1987b. Deciduous teeth of the Neanderthal mandible from Molare Shelter, near Scario (Salerno, Italy). American Journal of Physical Anthropology 79, 475-482.

Mastronuzzi, G., Sansò, P., 2002. Pleistocene sea level changes, sapping processes and development of valleys network in Apulia region (southern Italy). Geomorphology 46, 19-34.

Matijašić, R., 1993. Oil and wine production in Istria and Dalmatia in classical Antiquity and the early Middle Ages. In: Amouretti, M.C., Brun, J.P. (Eds.), La production du vin et de l'huile en Méditerranée, pp. 247-261. BCH suppl. 26, Athens.

Matijašić, R., 2007. Impianti antichi per olio e vino in contesto urbano in Istria. Histria Antiqua 15, 13-26.

Mattingly, D.J., Hitchner, B., 1993. Technical specifications for North African olive presses. In: Amouretti, M.C., Brun, J.P. (Eds.), La production du vin et de l'huile en Méditerranée, pp. 439-462. BCH suppl. 26, Athens.

Ollà, A., 2004. Ceramica da Bagnoli e S. Gregorio: importazioni e produzioni locali. In: Spigo, U. (Ed.), Archeologia a Capo d'Orlando. Studi per l'Antiquarium, Milazzo (Me), pp. 109-140.

Orlandos, A.K., 1968. Les matériaux de construction et la technique architectural des anciens Grecs. II partie, Paris.

Parsons, A.W., 1936. A Roman water-mill in the Athenian agora. Hesperia 5, 70-90.

Peacock, D.P.S., 1986. The production of Roman millstone near Orvieto, Umbria, Italy. Antiquaries Journal 66 (I), 45-51.

Peacock, D.P.S., 1989. The mills of Pompeii. Antiquity 63 (238), 205-214.

Pinzone, A., 2004. Agatirno: spunti di storia istituzionale ed economica. In: Spigo, U. (Ed.), Archeologia a Capo d'Orlando. Studi per l'Antiquarium, Milazzo (Me), pp. 17-22.

Poccetti, P., 1996. Aspetti linguistici e toponimastici della storia marittima dell'Italia antica. In: Prontera 1996, pp. 35-73.

Rockwell, P., 1992. Lavorare la pietra. Manuale per l'archeologo. Roma.

Romano, R., 2008. Polignano a Mare e la sua storia. Bari.

Ronchitelli, A., 1993. Paleosuperfici del Paleolitico Medio al Molare di Scario (Salerno). In: Paleosuperfici del Pleistocene e del primo Olocene In Italia. Processi di formazione e interpretazione, Atti della XXX Riunione Scientifica IIPP (Venosa-Isernia, 26-29 Ottobre 1991), Firenze, pp. 233-246.

Ronchitelli, A., Freguglia, M., Boscato, P., 2010. Paléoécologie et stratégies de subsistance à l'Abri du Molare de Scario (S. Giovanni a Piro - Salerne - Italie du Sud): niveaux Paléolithique moyen 44-49, données préliminaires. In: Canard, N.J., Delagnes, A. (Eds.), Settlement Dynamics of the Middle Paleolithic and Middle Stone Age, III. Kerns Verlag Tübingen, pp. 249-264.

Ronchitelli, A., Boscato, P., Surdi, G., Masini, F., Petruso, D., Accorsi, C.A., Torri, P., 2011. The Grotta Grande of Scario (Salerno, Italy): archaeology and the environment during the last interglacial (MIS 5) of the Mediterranean region. Quaternary International 231, 95-109.

Rosada, G., 2007. Torcularia: tra fonti e archeologia. Histria Antiqua 15, 213-228.

Scagliarini Corlàita, D., 1994. La villa di Desenzano. Vicende architettoniche e decorative. In: Studi sulla villa romana di Desenzano, Milano, pp. 43-58.

Schmiedt, G., 1972. Il livello antico del mar Tirreno. Firenze.

Schmiedt, G., 1975. Antichi porti d'Italia. Gli scali fenicio-punici. I porti della MagnaGrecia, Firenze.

Scibona, G., 1985. s.v. Capo d'Orlando. In: Nenci, G., Vallet, G. (Eds.), Bibliografia Topografica della Colonizzazione Greca in Italia, IV, p. 426. Roma.

Scicchitano, G., Antonioli, F., Castagnino Berlinghieri, E.F., Dutton, A., Monaco, C. 2008. Submerged archaeological sites along the Ionian coast of south-eastern Sicily (Italy) and implications with the relative sea level change during the late Holocene. Quaternary Research 70, 26-39.

Scicchitano, G., Lo Presti, V., Spampinato, C.R., Gasparo Morticelli, M., Antonioli, F, Auriemma, R., Ferranti, L., Monaco, C., 2011. Millstone as indicators of relative sea-level changes in northern Sicily and southern Calabria coastlines, Italy. Quaternary International 232, 92-104.

Spampinato, C.R., Scicchitano, G., Ferranti, L., Monaco, C., 2012. Raised Holocene paleoshorelines along the Capo Schisò coast, Taormina: new evidence of recent coseismic deformation in northeastern Sicily (Italy). Journal of Geodynamics 55, $18-31$.

Spampinato, C.R., Ferranti, L., Monaco, C., Scicchitano, G., Antonioli, F., 2014. Raised Holocene paleo-shorelines along the Capo Vaticano coast (Western Calabria, Italy): evidence of co-seismic and steady-state deformation. Journal of Geodynamics. http://dx.doi.org/10.1016/j.jog.2014.03.003.

Spigo, U., 1995. Capo d'Orlando: il complesso termale di età imperiale romana di Bagnoli e S. Gregorio. Scavi 1987 e 1992. In: Atti dell'VIII Congresso Internazionale di Studi sulla Sicilia Antica, pp. 1027-1037.

Spigo, U., 2004a. Il territorio di Capo d'Orlando nell'Antichità: nota introduttiva. In: Spigo, U. (Ed.), Archeologia a Capo d'Orlando. Studi per l'Antiquarium, Milazzo (Me), pp. 11-16.

Spigo, U., 2004b. Il complesso termale di località di Bagnoli e S. Gregorio. In: Spigo, U. (Ed.), Archeologia a Capo d'Orlando. Studi per l'Antiquarium, Milazzo (Me), pp. 91-108.

Spigo, U., Ollà, A., Capelli, C., 2004. La ceramica di produzione locale dalle terme di Bagnoli-S. Gregorio a Capo d'Orlando (Me). In: Malfitana, D., Poblome, J., Lund, J. (Eds.), Old Pottery in a New Century. Innovating Perspectives on Roman Pottery Studies. Atti del Convegno Internazionale di Studi (Catania, 22-24 aprile 2004) Catania, pp. 451-464.

Starac, A., 2010. Dragonera. Two Pearls, Pula.

Sulli, A., Lo Presti, V., Gasparo Morticelli, M., Antonioli, F., 2013. Vertical movements in NE Sicily and its offshore: outcome of tectonic uplift during the last $125 \mathrm{ky}$. Quaternary International 288, 168-182.

Tagliente, P., 2005. Soleto (Le): i materiali di età medievale e moderna da un saggio d scavo nel centro storico. Quaderni della ceramica di Cutrofiano 10 (I), 27-102.

Tassaux, F., 2010. Les milliardaires de l'Adriatique romaine. Bordeaux.

Toker, E., Sivan, D., Stern, E. Shirman, B., Tsimplis, M., Spada, G., 2011. Evidence for centennial scale sea level variability during the Medieval Climate Optimum (Crusader Period) in Israel, eastern Mediterranean. Earth and Planetary Science Letters 315-316, 51-61.

Turano, C., 1970. Leucopetra. Archeologia Classica XXII 22, 164-168.

Ucosich, A., 2011. Rinvenimento di un'antica cava di pietre da macina nel litorale d Letojanni (ME). Bollettino dell'Ordine dei Geologi di Sicilia XIX (1), 32-39.

Volpe, G., 1996. Contadini, pastori e mercanti nell’Apulia tardoantica. Bari.

Wikander, O., 1979. Water-mills in ancient Rome. OpRom, 12, pp. 13-36.

Wikander, O., 1984. Exploitation of Water Power or Technological Stagnation? A Reappraisal of the Production Forces in the Roman Empire. Lund.

Williams, D., Peacock, D. (Eds.), 2011. Bread for the People. The Archaeology of Mills and Milling. Proceedings of a Colloquium Held in the British School at Rome 4th-7th November 2009. BAR I.S. 2274, Oxford.

Williams-Thorpe, O., 1988. Provenancing and archaeology of Roman millstone from the Mediterranean area. Journal of Archaeological Science 15, 253-305.

Williams-Thorpe, O., 1993. Geochemistry and trade of eastern Mediterranean millstone from the Neolithic to Roman periods. Journal of Archaeological Science 20, 263-320.

Wilson, A., 2001. The water-mills on the Janicu-lum. Memoirs of the American Academy at Rome 45, 219-246.

Yeivin, Z., 1966. Two Ancient Oil Presses. Atiqot, 3 (Hebrew Series), pp. 51-62. 